\title{
A matematização dos estudos elétricos antes de Coulomb: as contribuições de Johann Euler no século XVIII, acompanhada de uma tradução comentada de seu Recherches sur la Cause Physique de l'Electricité
}

The mathematization of electrical studies before Coulomb: the contributions of Johann Euler in the 18th century, alongside a commented Portuguese translation of his Recherches su la Cause Physique de l'Electricité

\author{
Lucas Marcelo Cavalari Nardi*1] ${ }^{*}$ Cibelle Celestino Silva ${ }^{1}$ \\ ${ }^{1}$ Universidade de São Paulo, Instituto de Física de São Carlos, Grupo de História, Teoria e Ensino de Ciências, São Carlos, \\ SP, Brasil
}

Recebido em 20 de setembro de 2020. Revisado em 21 de outubro de 2020. Aceito em 14 de novembro de 2020.

\begin{abstract}
A matematização da física passou a ser tomada como algo intrínseco a esse ramo da filosofia natural ao longo do século XVIII, após o grande sucesso na mecânica newtoniana. A matematização da eletrostática, por sua vez, é comumente associada aos trabalhos de Charles-Augustin Coulomb que usam a abordagem newtoniana de ação à distância. Porém, tentativas de matematizar teorias elétricas ocorreram antes de Coulomb, utilizando outras abordagens conceituais que não a ação à distância. Um exemplo é o trabalho Recherches sur la Cause Physique de l'Electricité de Johann Albrecht Euler. Nele, Johann Euler constrói, com o auxílio de conceitos da hidrodinâmica e do cálculo, equações que relacionam a densidade e a velocidade do éter movendo-se dentro dos poros de um corpo, explicando assim fenômenos eletrostáticos como atração e repulsão. O debate sobre qual seria a melhor forma de entender o mundo, seja por ação à distância, seja pela existência de um éter, adentra o século XIX e influencia o desenvolvimento do eletromagnetismo e da relatividade. Neste artigo, trazemos um estudo histórico centrado no trabalho de Euler que dialoga com o contexto científico do período seguido de uma tradução comentada da obra Recherches sur la Cause Physique de l'Electricité, publicada em 1759.
\end{abstract}

Palavras-chave: História da Física, Matematização, Eletricidade no século XVIII.

The mathematization of physics became something intrinsic to this branch of natural philosophy throughout the 18th century, after its great influence in Newtonian mechanics. The mathematization of electrostatics is commonly associated with Charles-Augustin Coulomb, who uses the Newtonian notion of action at a distance. However, attempts to mathematize electrical theories occurred before Coulomb, using conceptual approaches other than action at a distance. One example is the work Recherches sur la Cause Physique de l'Electricité by Johann Albrecht Euler. In it, Johann Euler builds - using concepts common to hydrodynamics and calculus equations that relate the density and the velocity of the ether moving within the pores of a body, thereby explaining electrostatic phenomena such as attraction and repulsion. The debate on what would be the best way to understand physical interactions (whether by forces at a distance or by the existence of ether) goes into the 19th century and influences the development of electromagnetism and relativity. In this article, we bring a historical study centered on Johann Euler's work embraced by the scientific context of the period. In addition, we present a commented translation to Portuguese of the work Recherches sur la Cause Physique de l'Electricité, published in 1759 .

Keywords: History of physics; Mathematization; Electrical studies in the 18th century.

\section{Introdução}

Narrativas clássicas sobre a história da ciência costumam concentrar-se nos feitos de pessoas mais famosas, contribuindo para aumentar suas famas e tornando ainda menos conhecidas as contribuições de pesquisadores que

\footnotetext{
*Endereço de correspondência: lucas.nardi@usp.br
}

por várias razões não entraram no seleto grupo de celebridades históricas. No caso da eletricidade, entre os personagens famosos do século XVIII, destacam-se Stephen Gray (1666-1736), Benjamin Franklin (17061790) e Charles-Augustin Coulomb (1736-1806).

Com a intenção de ampliar a visão histórica sobre o período, trazemos uma tradução comentada do trabalho Recherches Sur la Cause Physique de l'Electricité, de 
Johann Albrecht Euler (1734-1800) 1Além de expandir a visão sobre os estudos elétricos no século XVIII, vale destacar que Johann Euler inova ao utilizar um aparato matemático antes utilizado nos estudos da hidrodinâmica para exemplificar algumas aplicações de sua teoria etérea para a eletricidade, algo bastante inovador para a época, já que ele parece ser um dos poucos, se não mesmo um dos primeiros, a fazer uso de técnicas e recursos matemáticos em uma teoria etérea da eletricidade, equiparando-se apenas aos trabalhos de Leonhard Euler sobre o éter, que foram feitos no contexto da óptica, e não da eletricidade ${ }^{2}$

Antes da tradução, porém, cabe-nos expor o contexto das pesquisas sobre eletricidade no século XVIII. Até a primeira metade do século, o conhecimento acerca dos fenômenos elétricos dizia respeito aos objetos que tinham a propriedade de atrair corpos leves quando atritados. O inglês Francis Hauksbee (1660-1713), no começo do século XVIII, inventou um gerador capaz de eletrificar vidro por atrito de maneira mais fácil e rápida. $\mathrm{Na}$ época, os fenômenos básicos foram isolados e descritos, a saber, a atração, a repulsão e a atração seguida pela repulsão após contato entre um corpo neutro e outro carregado [1, 2].

Até 1745, vários fenômenos já haviam sido categorizados como de natureza elétrica sendo que a formulação teórica para explicá-los mais influente na época era a proposta pelo francês Jean-Antoine Nollet ${ }^{3}(1700-1770)$. Uma grande variedade de possibilidades experimentais estava posta a quem se interessasse pelo tema. Entre estes estavam Ewald Jürgen von Kleist (1700-1748) e Pieter (ou Petrus) van Musschenbroek (1692-1761), cujos estudos experimentais levaram à invenção do dispositivo hoje conhecido como garrafa de Leiden.4

Na mesma época, Benjamin Franklin começa a se interessar pelos fenômenos elétricos após receber de Peter Collinson (1694-1768), por volta de 1746, um tubo de vidro e descrição de alguns experimentos que poderiam ser realizados com ele. Ao longo de 1747, Franklin envia duas cartas a Collinson detalhando seus experimentos e suas ideias sobre eletricidade. Entre elas, o "poder das pontas", o conceito de dois estados de eletricidade, a existência de um único fluido elétrico que produzia "atmosferas elétricas" em corpos carregados, estas responsáveis pela atração e repulsão.

Como as ideias e experimentos de Franklin são bastante citados por Johann Euler, vale explicar algumas

\footnotetext{
1 Seu trabalho foi escrito em francês, língua oficial da Academia Real de Ciências de Berlim. Como essa não era sua língua materna, Euler comete alguns pequenos erros gramaticais e utiliza a expressão escrita russa, na qual a pontuação funciona de uma maneira diferente daquela em francês e português.

2 Para mais sobre a óptica de Leonhard Euler, ver a referência 3

3 Para mais sobre a teoria de Nollet, que não veremos aqui por que foge do escopo do artigo, ver: [7. Além de: 8].

${ }^{4}$ Para mais sobre os experimentos de Kleist e sua falta de recepção, e de Musschenbroek e sua recepção na Europa, ver: 9]. Além da referência [2] p. 309-343].
}

delas $5^{5}$ Em resumo, para Franklin, os corpos materiais são constituídos por matéria comum e fluido elétrico, e este constituído por partículas. Todo corpo possui uma quantidade natural de fluido elétrico 6 Se um corpo tivesse mais fluido que sua quantidade natural, estaria no estado positivo (ou simplesmente mais). Se possuísse menos que a quantidade natural, estaria no estado negativo (ou simplesmente menos). Quando o fluido se acumula em um corpo, tem-se um excedente de fluido que o circunda, criando uma atmosfera elétrica. A aproximação de dois corpos positivos resultava em uma repulsão porque as suas atmosferas elétricas resistem à fusão, no entanto a repulsão entre dois corpos no estado negativo não é explicada por este modelo [4].

\section{Os Trabalhos Sobre Eletricidade de Johann Euler}

Johann Albrecht Euler 7 nascido na Rússia, era o filho mais velho do matemático Leonhard Euler (1707-1783), cujos trabalhos são muito mais lembrados que os de seu filho. Johann Euler foi um acadêmico bem relacionado da segunda metade do século XVIII [5, 6], vivendo em Berlim de 1741 até 1766 . Depois, foi nomeado professor de física na Academia de São Petersburgo e, a partir de 1769, tornou-se secretário de conferências e, portanto, responsável pelas correspondências da Academia [6. p. 195] 8

Ele escreveu dois trabalhos sobre eletricidade $9^{9} \mathrm{O}$ primeiro trabalho, intitulado Disquisitio de Causa Physica Electricitatis 10 foi enviado à Academia de Ciências e Artes de São Petersburgo no fim de 1754 por seu pai no

\footnotetext{
5 Para mais detalhes sobre a teoria de Franklin e sua recepção, ver: [10].

6 Em uma carta a Peter Collinson datada de setembro de 1753, Franklin explicita sua definição de quantidade natural de fluido elétrico de um corpo como aquela que os corpos contêm enquanto não apresentam sinais de eletrificação entre si [1].

7 Neste artigo usaremos a versão internacionalizada de seu nome, que é "Johann Albrecht", derivada da transcrição russa de seu nome. Johann Euler assinava suas cartas "Jean Albert", seu nome em francês 5 p. 443].

8 Entre 1773 e 1774, Johann Euler e seu pai se envolveram em uma querela acadêmica com Denis Diderot (1713-1784). Na época Diderot chegou a ficar na Academia de São Petersburgo por, aproximadamente, cinco meses. Para mais, ver: 12.

9 Há trabalhos historiográficos que questionaram a autoria de Johann Euler nesses dois trabalhos, atribuindo-as a Leonhard Euler. Porém, o historiador Roderick W. Home resume esses questionamentos e apresenta uma defesa bastante convincente baseada em cartas de Johan C. Wilcke e Franz U. T. Aepinus a favor da autoria de Johann A. Euler nos dois trabalhos 13. Além disso, no contexto do primeiro trabalho de Johann Euler, Leonhard Euler em uma carta a Gerhard Friedrich Müller (17051783) deixa claro que, após pensar sobre os fenômenos elétricos, passou suas ideias ao filho, que escreveu a obra de 1754 (publicadas em 1757) [16, p. 92-93]. Portanto, é provável - e razoável de se esperar - que Leonhard Euler tivesse influenciado a teoria sustentada pelo filho. Mas, mesmo assim, é leviano.

10 Em português, "Uma dissertação das causas físicas da eletricidade".
} 
contexto de uma competição organizada pela Academia de São Petersburgo [13] ${ }^{11}$

Neste primeiro trabalho, escrito em 1754 e publicado em 1757, Johann Euler propõe um modelo baseado no éter para explicar a eletricidade sob clara influência de seu pai, que defende que o éter era a causa mecânica da gravidade e da luz. Johann Euler atribui ao éter uma rarefação e um alto grau de elasticidade, pois, segundo ele, essas propriedades emergiam dos estudos sobre a natureza da luz [14, p. 68-73].

A eletrização é interpretada como a expulsão de uma quantidade de éter dos poros de um corpo, o estado positivo ou negativos depende da relação entre a elasticidade do éter no corpo e no ar ao redor. Se um corpo com poros livres, ou seja, neutro, toca um já eletrizado, a eletrização é destruída, pois o primeiro funciona como um escape para o éter preso no segundo. Caso o corpo neutro apenas se aproxime do eletrizado, sem tocálo, o éter acabará sendo agitado devido ao efeito do éter presente no ar, podendo resultar em faíscas, ou até mesmo fogo, dependendo do grau de agitação 14, p. $68-73]$.

Algumas definições do primeiro trabalho de Johann Euler aparecem no segundo, o Recherches Sur la Cause Physique de l'Electricité. Por exemplo, sobre os tipos de corpos. Os corpos elétricos per se, ou seja, os corpos que podiam ser eletrizados por atrito, tinham seus poros mais estreitos. Também havia os não-elétricos (ou nãoelétricos per se) que não podiam ser eletrizados por atrito, pois possuíam poros menos estreitos 12

Johann Euler descreve o princípio que rege sua teoria neste segundo trabalho: "Que os fenômenos da eletricidade são causados pela força elástica do éter quando esse fluido não está em equilíbrio dentro dos corpos vizinhos." [15, p. 126]. Segundo o autor, o éter é uma matéria que permeia todos os corpos. Benjamin Franklin havia proposto a existência de uma fluido elétrico, mas para Johann Euler isso não passava de outro nome para o éter, cuja existência não poderia ser posta em dúvida [15. p. 127].

Afastando-se da concepção de Benjamin Franklin, Euler afirma que não é possível conceber a matéria elétrica como uma atmosfera que envelopa os corpos, já que "tanto a violência, quanto a rapidez, parecem, em primeira análise, destruir a ideia de uma atmosfera, em qualquer agitação que se queira concebê-la." [15, p. 128].

\footnotetext{
11 O texto foi enviado seis meses após a morte de Georg Wilhelm Richmann (1711-1753) sendo, muito provavelmente, em sua homenagem. Richmann morreu em uma tempestade em decorrência de um choque elétrico enquanto fazia experimentos elétricos que envolviam o estudo de raios [2 p. 390-392].

12 Os metais só foram eletrizados por atritos em 1778 e, depois, em 1780 por, respectivamente, Joseph von Herbert [17, p. 15-16] e Hemmer [18. Apesar da eletrização dos metais por atrito ter afetado profundamente a divisão comum à época entre elétricos per se e não-elétricos, já existia certa insatisfação com essa divisão, como pode ser visto na carta de Benjamin Franklin para Cadwallader Colden (1688-1776) de 23 de abril de 1752 [10. p. 128].
}

Johann Euler utiliza um argumento epistemológico para igualar o fluido elétrico de Franklin ao seu éter, afirmando que é "contrário às regras de uma boa Física multiplicar a bel prazer as matérias sutis (...)" [15. p. 129]. Esse argumento é baseado em um princípio conhecido como "Navalha de Occam". Esse princípio diz que não se deve multiplicar entidades em uma teoria sem necessidade, optando-se sempre pela teoria mais simples ${ }^{13}$ No entanto, na época, nem todos utilizavam essa regra epistemológica para assumir a existência de um único tipo de matéria associada aos fenômenos elétricos. Por exemplo, Franz Aepinus (17241802), em seu livro Tentamen Theoriae Electricitatis et Magnetismi, publicado em 1759, nega a igualdade entre éter e fluido elétrico, trabalhando apenas com este último. Além disso, ele também assume a existência de outros fluidos na natureza, como o magnético, por exemplo [14].

Em várias passagens de seu trabalho, Johann Euler critica a teoria de um único fluído elétrico de Franklin. Por exemplo, em seu primeiro trabalho sobre eletricidade, Euler havia afirmado que não existiam dois estados elétricos, diferentemente do que afirmavam muitos autores na época, entre eles Benjamin Franklin. Johann Euler acreditava na existência de apenas um estado elétrico que se manifestaria de duas formas. O suposto segundo estado elétrico seria, para Johann Euler, uma ilusão, pois as eletricidades vítrea e resinosd 14 são características únicas dos corpos; logo, só havia uma eletricidade, isto é, um estado elétrico. No seu segundo trabalho, Euler passou a aceitar a existência de dois estados elétricos distintos por influência de Franz Ulrich Theodosius Aepinus, um adepto da teoria de um fluido elétrico de Franklin e da ação à distância.

Apesar de Johann Euler discordar de Franklin em vários pontos, ele mantém alguns conceitos de Franklin. Entre eles, o de estado natural, no qual o éter "enclausurado dentro dos poros dos corpos fosse, em todo canto, dotado do mesmo grau de elasticidade, ele se encontraria em um perfeito equilíbrio, e não faria nenhum esforço de sair de um [corpo] para entrar em um outro (... )" [15. p. 132]. Assim, são necessárias duas condições para que um corpo se eletrize. A primeira é a de que "o éter enclausurado em diferentes corpos se encontre em diferentes graus de elasticidade, e a outra é que os poros dos corpos que contêm o éter não sejam, nem completamente abertos, nem completamente bloqueados." [15, p. 133].

\footnotetext{
13 Isaac Newton (1643-1727) já havia utilizado esse argumento antes, para mais ver: [20].

14 Esses dois tipos de eletricidade advêm dos trabalhos do francês Charles François de Cisternay Dufay (1698-1739) nos anos de 1730. Dufay afirmou esses dois tipos de eletricidade no contexto de seus estudos sobre a repulsão elétrica. Ele defendia que não somente a atração entre corpos eletrizados - primeiro fenômeno elétrico a ser notado - era um fenômeno elétrico, mas que a repulsão entre corpos também era essencialmente elétrica. A repulsão já havia sido notada, mas não havia sido pensa de tal forma [21].
} 
Um importante ponto de discordância entre os dois autores, dentre os vários existentes, é em relação à definição de estados positivo e negativo. Na seção 5 discutimos essa diferença em mais detalhes.

\section{A Matematização do Éter: Uma Nova Forma de Pensar a Eletrostática}

Ao longo do século XVIII, teorias físicas passaram a ser mais e mais matematizadas, muito devido à influência dos estudos de Isaac Newton (1642-1727) sobre mecânica. A matematização de uma teoria é aqui entendida como a formulação de expressões matemáticas abstratas, geométricas e/ou algébricas [19, p. 407-408] para descrever relações entre entes físicos ou mesmo os próprios entes. Dessa forma, a matemática atua como um novo instrumento que auxilia a construção de argumentos e explicações, sendo pouco a pouco confundida com o próprio objeto de estudo. A história da matematização da física é complexa, mas podemos tomar como ponto de partida os trabalhos de Newton, pelo menos no que diz respeito ao século XVIII. Eles são um excelente exemplo de uma matematização (na forma geométrica) da mecânica, pois demonstravam, com o uso da ação à distância e da geometria, os fatos observados (e a serem observados) pelos filósofos da época [22]. A geometria era, pois, o principal alicerce da matemática até então 23 .

Vale ressaltar que é enganoso interpretar Newton como alguém que rejeitou ou desdenhou de pesquisas utilizando explicações mecanicistas para a gravidade, como teorias etéreas. Ao longo de sua carreira ele estudou diversas delas, mas pela dificuldade que elas impuseram, Newton acabou por não as abordar no Principia (pelo menos não em detalhes). Assim, o entendimento de Newton, grosso modo, é o de que, apesar de uma teoria mecanicista para a gravidade ser desejável, ela seria muito difícil (talvez impossível) e, portanto, a ação à distância seria uma abordagem possível e útil de ser postulada. Logo, o newtonianismo do século XVIII abandona o mecanicismo e adota a força à distância [24 p. 80-89]. Os pesquisadores sobre eletricidade que adotavam uma perspectiva newtoniana também abandonaram explicações baseadas em éter ou em fluído elétrico e adotaram a ação à distância para explicar os fenômenos elétricos, entre eles Aepinus e Coulomb.

Em nosso recorte histórico, pudemos observar que, com o avanço do conceito matemático de função, a mecânica tornou-se mais algébrica. Essa mudança foi parcialmente influenciada por Leonhard Euler, que escreveu diversos trabalhos sobre mecânica entre 1736 e 1782 [25, 26, p. 101-194]. A mecânica passa, assim, para uma matematização mais algébrica. Um estágio avançado desse processo pode ser visto no Mechanique Analitique de Joseph-Louis Lagrange (1736-1813), publicado em 1788. Nele não há figuras nem geometria, apesar de se tratar de um estudo matematizado sobre mecânica [27. Dessa forma, vemos um movimento que parte de uma matematização geométrica para uma algébrica ao longo do século XVIII. É nesse contexto que a obra de Johann Euler se encontra. Junto com o desenvolvimento do cálculo e da hidrodinâmica [28, foi possível construir teorias etéreas matematizadas para a eletricidade tratando o éter como um fluido, dotado de características típicas de um fluido, como densidade, velocidade e pressão.

Isso é justamente o que Johann Euler faz em seu trabalho Recherches Sur la Cause Physique de l'Electricité, no qual produz equações para o movimento do éter no contexto da eletricidade, constituindo uma matematização deste. Por mais que seu trabalho não tenha ganhado visibilidade na época, a abordagem utilizada pode ter influenciado os estudos posteriores sobre o éter eletromagnético.

Após os comentários iniciais do Recherches Sur la Cause Physique de l'Electricité, no vigésimo parágrafo, Johann Euler começa a utilizar o cálculo para obter resultados teóricos sobre a eletricidade, mesmo que em casos idealizados. Até então não havia teorias matematizadas utilizando formulações matemáticas abstratas (geométricas ou algébricas) com papel estruturante sobre fenômenos elétricos. No caso, veremos Johann Euler construindo equações a partir de suas suposições sobre o éter, usando assim a estrutura do cálculo diferencial para modelar alguns exemplos particulares de aplicação de sua teoria. Vale ressaltar que suas explicações ainda tinham um aspecto fenomenológico, onde observações empíricas são centrais, mas sua teoria possuía conteúdos teóricos matematizados, o que era bastante inovador para a eletrostática da época.

Como dito acima, havia estudos matematizados e robustos na hidrodinâmica, mas ainda não havia uma teoria etérea matematizada para a eletricidade, ao menos não com a produção de fórmulas gerais, com talvez a exceção de Paolo Frisi (1728-1784) que usou brevemente cálculos matemáticos em seu trabalho sobre a eletricidade, também baseado na existência de um éter [29]. O trabalho de Frisi competiu pelo prêmio da Academia de Ciências e Artes de São Petersburgo na mesma competição que Johann Euler acabou vencendo [2, p. 395-396]. Isso ilustra que tentativas de matematizar os fenômenos elétricos em uma abordagem mecanicista era uma tendência na época, constituindose uma abordagem alternativa às abordagens baseadas em ação à distância, como as de Aepinus e Coulomb.

\section{A Teoria Eletrostática Como Uma Hidrodinâmica do Éter}

Johann Euler utiliza diversas grandezas comuns à hidrodinâmica, aplicando-as ao éter, já que seu caráter ontológico era o de um fluido. Por exemplo, ao estudar o 


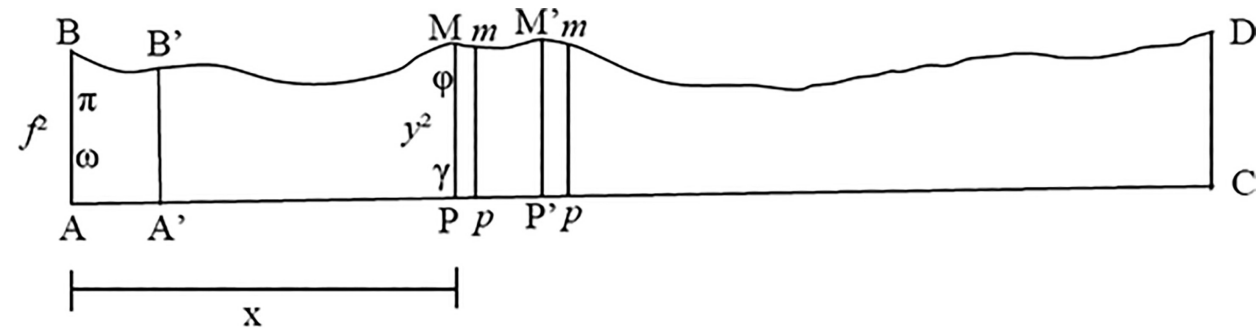

Figura 1: Uma versão adaptada da primeira figura do trabalho de Johann Euler de 1759. Nele, Johann Euler ilustra um poro de um corpo como um canal, sendo o éter um fluido atravessando-o. $\mathrm{Na}$ imagem os 'A', 'B', ' $\mathrm{P}$ ' e ' $\mathrm{M}$ ' mais à direita deveriam estar com uma apóstrofe cada, senão a construção matemática de Johann Euler não faria sentido. Esse erro tipográfico se encontra na imagem original. Aqui apresentamos a imagem corrigida.

Fonte: Adaptada, pelos autores, da referência [15].

movimento do éter dentro de um poro qualquer (o canal $\mathrm{ABCD}$ ) de um corpo, como ilustrado na Figura 1 . considera a densidade do éter em $\mathrm{AB}$ como $\pi$ e em $\mathrm{PM}$ como $\varphi$. Ele estabelece, então, uma relação de proporção direta entre densidade e elasticidade; isto é, quando a densidade é unitária, a elasticidade vale $n$. Então, a elasticidade em $\mathrm{AB}$ vale $n \pi$, e em PM, $n \varphi$. A velocidade em $\mathrm{AB}$ é igual a $\omega$, e em PM, $\gamma$. Além disso, a área da secção transversal em AB é $f^{2}$ e a da secção PM, $y^{2}$. Considerando o movimento de uma quantidade de éter em $\mathrm{ABPM}$ para $\mathrm{A}^{\prime} \mathrm{B}^{\prime} \mathrm{P}^{\prime} \mathrm{M}^{\prime}$ depois de transcorrido um tempo $d t$, Johann Euler constrói a seguinte equação para representar a variação de éter num trecho de um poro do corpo eletrizável em questão:

$$
f^{2} \pi \omega-y^{2} \varphi \gamma=\int y^{2} d x\left(\frac{\partial \varphi}{\partial t}\right)
$$

Em seguida, considera a força exercida pela diferença de elasticidade no éter enclausurado no trecho PMpm, isso dá a ele a força motriz de valor, em notação moderna, igual a -nyydx $\left(\frac{\partial \varphi}{\partial x}\right)$. Com isso, Johann Euler calcula a aceleração e, sabendo que o aumento da velocidade $d t\left(\frac{\partial \gamma}{\partial t}\right)+\gamma d t\left(\frac{\partial \gamma}{\partial x}\right)$, deve ser igual ao produto da aceleração pelo tempo $d t$, Euler obtém a segunda equação, a saber:

$$
\left(\frac{\partial \gamma}{\partial t}\right)+\gamma\left(\frac{\partial \gamma}{\partial x}\right)=-\frac{n}{\varphi}\left(\frac{\partial \varphi}{\partial x}\right)
$$

Assim, com as equações acima, Johann Euler constrói uma dinâmica do éter com um sistema de equações regendo o movimento do éter nos poros dos corpos que, a princípio, descreveriam qualquer fenômeno elétrico. Porém, "as fronteiras da Análise nos param aqui prontamente, e não poderíamos resolver, de maneira generalizada, as duas equações que acabamos de encontrar." [15, p. 139]. Não conseguindo resolvê-las em um caso genérico, ele se vale de aproximações; resolvendoas então para o caso específico no qual a densidade e velocidade em uma secção transversal não variam no tempo, isto é, encontra uma solução estacionária.

Notemos que a insolubilidade das equações gerais pode ser contestada, já que esse sistema pode ser resolvido utilizando-se algumas integrações 15

$$
\left\{\begin{array}{l}
\frac{\partial \varphi(x, t)}{\partial x}+\varphi(x, t)\left[\frac{1}{n}\left(\frac{\partial \gamma(x, t)}{\partial t}+\gamma(x, t) \frac{\partial \gamma(x, t)}{\partial x}\right)\right]=0 \\
\int y^{2}(x) \frac{\partial \varphi(x, t)}{\partial t} d x+\varphi(x, t)\left(\gamma(x, t) y^{2}(x)\right) \\
=\pi(x, t) \omega(x, t) f^{2}(x) .
\end{array}\right.
$$

Usando três funções aqui definidas como $g(x, t) \stackrel{\text { def }}{=} \frac{1}{n}\left(\frac{\partial \gamma(x, t)}{\partial t}+\gamma(x, t) \frac{\partial \gamma(x, t)}{\partial x}\right), F(x, t) \stackrel{\text { def }}{=} \gamma(x, t) y^{2}(x)$ e $H(x, t) \stackrel{\text { def }}{=} \pi(x, t) \omega(x, t) f^{2}(x)$, o sistema se torna mais simples e temos:

$$
\left\{\begin{array}{c}
\frac{\partial \varphi(x, t)}{\partial x}+\varphi(x, t) g(x, t)=0 \\
\int y^{2}(x) \frac{\partial \varphi(x, t)}{\partial t} d x+F(x, t) \varphi(x, t)=H(x, t) .
\end{array}\right.
$$

Podemos integrar a primeira equação do sistema acima, assim:

$$
\varphi(x, t)=C_{1}(t) e^{-\int g(x, t) d x} .
$$

Onde $C_{1}(t)$ é uma função arbitrária. Podemos também derivar a segunda equação para removermos a integral em $x$. Depois, usando duas novas funções aqui definidas como $p(x, t) \stackrel{\text { def }}{=} \frac{1}{y^{2}(x)}\left[\frac{\partial F(x, t)}{\partial x}-F(x, t) g(x, t)\right] \mathrm{e}$ $h(x, t) \stackrel{\text { def }}{=} \frac{1}{y^{2}(x)} \frac{\partial H(x, t)}{\partial x}$, teremos:

$$
\frac{\partial \varphi(x, t)}{\partial t}+p(x, t) \varphi(x, t)=h(x, t)
$$

A equação acima também pode ser resolvida com uma integração:

$$
\varphi(x, t)=e^{-\int p(x, t) d t}\left(\int h(x, t) e^{\int p(x, t) d t} d t+C_{2}(x)\right) .
$$

\footnotetext{
15 Aqui optamos por usar a notação moderna por questão de clareza, mas a notação da época difere pouco e poderia ser usada sem grandes dificuldades.
} 
Onde $C_{2}(x)$ é uma função arbitrária. Porém, como as duas soluções são soluções para a mesma função $\varphi(x, t)$, temos necessariamente uma relação entre as duas funções arbitrárias. Essa relação pode ser simplificada e resulta na seguinte expressão:

$$
\begin{aligned}
C_{2}(x)= & C_{1}(t) e^{-\int g(x, t) d x} e^{-\int p(x, t) d x} \\
& -\int h(x, t) e^{\int p(x, t) d x} d t .
\end{aligned}
$$

Com isso, se as duas funções arbitrárias obedecerem a relação deduzida, teremos ao menos uma solução para o sistema proposto por Johann Euler. Essa técnica de integração para resolver equações diferenciais já existia, tendo sido usada por Leonhard Euler, além de outros matemáticos e filósofos naturais da época [30.

O próprio Leonhard Euler foi bastante decisivo para o estudo de equações diferenciais, valendo-se de várias técnicas usadas até hoje para resolvê-las [31. É claro que é muito difícil saber se essas equações estavam no escopo do que podia ser resolvido na época. Se eram passíveis de serem resolvidas, fica a questão de porque Johann Euler não o ter feito, e por que ele parece seguro ao afirmar que não há possibilidade de solução generalizada. Talvez elas fossem muito complicadas para a época de fato. De qualquer maneira, seu pai (ou de algum dos Bernoulli) poderiam tê-lo ajudado a resolvê-las. Vale lembrar que algumas das principais obras sobre equações diferenciais, como o Methodo incrementorum de Brook Taylor (16851731) já haviam sido publicadas (nesse caso, em 1715). Mas, o Calculi Integralis de Leonhard Euler não, sendo publicado apenas em 1768 16 Logo, não podemos fixar claramente se essas equações eram - ou não - de fácil resolução no final dos anos 1750 .

Johann Euler consegue resolvê-las apenas para um caso simplificado - quando as derivadas parciais no tempo zeram, obtendo das equações (1) e (2) que

$$
\varphi=\pi\left(e^{\left(\omega^{2}-\gamma^{2}\right) / 2 n}\right) .
$$

Essa solução pode ser simplificada para

$$
\varphi=\pi\left(1+\left(\omega^{2}-\gamma^{2}\right) / 2 n\right)
$$

por expansão em Taylor, que já era usada desde pelo menos 1715 32, mas Johann Euler continua simplificando. A equação (1) torna-se $f^{2} \pi \omega=y^{2} \varphi \gamma$. Assumindo que as densidades, $\pi$ e $\varphi$, não variam ao longo do tubo e, portanto, podem ser canceladas, temos então a expressão $f^{2} \omega=y^{2} \gamma$. Dessa forma, o resultado da equação 10 é:

$$
\varphi=\pi\left(1-\frac{\omega^{2}}{2 n y^{4}}\left(f^{4}-y^{4}\right)\right) .
$$

$\overline{16}$ Apesar disso, Leonhard Euler já estava estudando esse assunto há algum tempo. Sua Methodus inveniendi líneas curvas maximi minive proprietate gaudentes, um estudo de variações para calcular máximos e mínimos, foi publicado em 1744. Para mais, ver: 31.
Assim, na região em que a área da secção transversal é maior, $f^{2}$, por exemplo (secção $\mathrm{AB}$ ), a elasticidade também é maior; no caso, $n \pi$, em relação a outra secção, como, por exemplo, PM. Essa solução (11), uma aproximação, só foi possível admitindo que a densidade do éter não varia ${ }^{17}$ ao longo do tubo ABCD. Johann Euler prossegue sua análise e, voltando à solução $(9)$, vêse que onde a velocidade $\omega$ é maior, a elasticidade $n \pi$ será menor, e vice-versa. Essa relação quantitativa explica a atração entre corpos de maneira não muito diferente do que proposto em seu primeiro trabalho; um corpo sempre é puxado em direção ao local onde a elasticidade do éter é menor. Em seu segundo trabalho, diferentemente do primeiro, ele pôde se apoiar em deduções matemáticas utilizando um formalismo matemático robusto. Assim, Johann Euler afirma:
ora, ainda que essa equação só aconteça quando o movimento do éter se tornou per- manente, o que nunca acontece, as conclusões que acabo de tirar acontecerão também quando o movimento já se aproxima de um estado de permanência, e poderemos até vê- las como gerais e aplicar desde os primeiros instantes do movimento, contanto que nos contenhamos com os enunciados gerais, sem determinar a proporção das elasticidades em relação às velocidades diferentes. Também é fácil de se convencer dessas conclusões grosso modo, pois, já que a elasticidade do éter faz esforço para pôr o corpo em movimento, assim que ela consegue produzir seu efeito, já que uma parte dos esforços é aí empregada, é necessário que a elasticidade seja aí diminuída, de modo que quanto maior for a velocidade, tanto menor deve ser a elasticidade. [15, p. 139-140]

Depois de analisar a atração e a repulsão entre corpos eletrizados, Johann Euler menciona a atração entre corpos que se encontram no mesmo estado elétrico (ambos positivos ou negativos) [15, p. 144]. Esse fenômeno

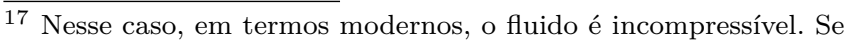
mantivermos a compressibilidade do fluido, basta aplicar $f^{2} \pi \omega=$ $y^{2} \varphi \gamma$ na solução $\varphi=\pi\left(1+\left(\omega^{2}-\gamma^{2}\right) / 2 n\right)$ e teremos $\frac{\varphi}{\pi}=$ $1+\frac{1}{2 n}\left(\frac{y^{4}}{f^{4}} \frac{\varphi}{\pi}-1\right) \gamma^{2}$. A expressão pode ser colocada da seguinte forma $\left(\frac{\varphi}{\pi}\right)^{2}\left(\frac{\gamma^{2}}{2 n}\left(\frac{y}{f}\right)^{4}\right)-\frac{\varphi}{\pi}+\left(1-\frac{\gamma^{2}}{2 n}\right)=0$. A equação algébrica acima é resolvida para a fração $\varphi / \pi$ por Bháskara, mas não resulta em uma expressão tão compacta e clara quanto a de Johann Euler e, assim, acaba não sendo útil. Se a densidade não varia ao longo do tubo, então a elasticidade, que é n (uma constante) vezes a densidade, também não varia. Isso impõe uma aparente inconsistência no trabalho de Johann Euler, pois, para ele, os fenômenos elétricos ocorrem devido às diferenças de elasticidade no éter em diferentes lugares. Felizmente, a equação (9), usada para explicar a atração e repulsão, independe dessa aproximação para a elasticidade. Subjacente a isso, encontra-se a dificuldade conceitual por trás da elasticidade, que discutiremos na seção6
} 
é contraintuitivo, mas ocorre ${ }^{18}$ Ele foi estudado de maneira aprofundada, na época, por Franz Aepinus [14]. No $37^{\circ}$ parágrafo, Johann Euler passa a analisar a comunicação elétrica, hoje mais conhecida como condução.

No $39^{\circ}$ parágrafo, Johann Euler explora a possibilidade de um corpo estar, em partes distintas, com estados elétricos distintos, como o que ocorre na garrafa de Leiden. No $41^{\circ}$ parágrafo, ele postula suas considerações sobre a estrutura da matéria, algo que havia posto como essencial para entender os fenômenos elétricos. Segundo ele haveria três tipos de corpos: os que mantêm o éter bem enclausurado, dificultando bastante seu movimento; os que permitem passagem livre ao éter; e um tipo intermediário que oferecem resistência parcial a passagem do éter.

Johann Euler prossegue discutindo a relação entre elasticidade e quantidade de éter quando pergunta retoricamente se

seria possível que a elasticidade do éter dentro de um corpo se tornasse maior sem que sua quantidade fosse aumentada, e que talvez o atrito produzisse tal efeito, assim como nós sabemos que o calor aumenta a elasticidade do ar sem que ele se torne mais denso. [15, p. 152]

Mas ele já responde sua pergunta afirmando que "[a conjectura] é destruída pelos próprios fenômenos da eletricidade que provam constantemente que, quando pelo atrito de dois corpos, um se torna positivamente eletrizado, observa-se no outro sempre uma eletricidade negativa, e vice-versa (... )" [15] p. 152]. Logo, quando há uma mudança na elasticidade do éter em algum corpo, há algum movimento do éter.

Embora bem estruturada e consistente, há algumas questões não esclarecidas no texto de Johann Euler. Por exemplo, no final de seu trabalho, ele discorre sobre a compressão dos poros de um corpo. Seu objetivo nessa parte do texto é explicar o motivo de, em sua teoria, os estados elétricos, como definidos por Franklin - positivo para excesso de fluido e negativo para falta -, precisarem ter suas definições invertidas. Para isso, Johann Euler distingue duas compressões. Uma delas é a aparente e surge quando se aperta ou amassa um corpo. Nesse caso, a lã é mais compressível que o vidro, seja ele polido ou áspero. Mas a compressão dos poros não deve, segundo ele, ser confundida com a compressão aparente; ou seja, a lã pode ser menos - e não mais - compressível que o vidro, se levarmos em conta apenas a compressão dos poros, e não a aparente. Assim, a compressão dos poros de um corpo não precisa ter relação com sua compressão aparente. Ao tratar da eletrização de uma porção de enxofre após ser derretida e resfriada, ele parece se valer

\footnotetext{
18 Para uma análise teórica desse fenômeno com os conhecimentos e técnicas matemáticas atuais de eletrodinâmica, ver a seção 2.3 de 33. Para uma análise, também atual, mas com uma explicação mais experimental, ver a seção 7.10 de [1].
}

de uma compressão aparente, a do resfriamento, para afirmar que os poros também encolhem no processo; ou seja, ele iguala a compressão aparente à compressão dos poros do enxofre, isso logo depois de afirmar que elas não são relacionadas. Ele não apresenta justificativas para tal igualdade.

No $55^{\circ}$ parágrafo, Johann Euler também assume que há uma relação entre esses dois tipos de compressão. Ainda no assunto de qual estado elétrico deve ser nomeado positivo, e qual deve ser nomeado negativo, Johann Euler afirma que "as Experiências feitas sobre a eletricidade de uma bola de breu ou de lacre achatada por um golpe de martelo nos conduzirão às mesmas conclusões que o enxofre derretido." [15, p. 156]. Nesse caso,

aceitando que os poros do breu pelo achatamento súbito se retraem, é necessário que a compressão do éter dentro desses poros aumente, o que mostraria uma eletricidade positiva. E como essa eletricidade é contrária àquela do vidro polido, esta será de fato negativa, contra a denominação do Sr. Francklin [Benjamin Franklin]. [15. p. 156]

Logo, mais uma vez sem justificativas, Johann Euler relaciona a compressão aparente causada pela martelada com a compressão dos poros do corpo golpeado, isso mesmo tendo afirmado que a compressão dos poros não deveria ser confundida com a compressão aparente.

\section{Afinal, O Que Seriam os Estados Positivo e Negativo?}

Um importante ponto de divergência entre Johann Euler e a teoria de Franklin era a definição dos estados positivo e negativo. Para Franklin, o estado positivo era um excesso de fluido elétrico no corpo. Mas para Johann Euler há arbitrariedade nisso, justamente porque se quer saber qual corpo está positivo, e qual está negativo. Definir os estados seria, então, um erro. Para Johann Euler, o simples caso de atritar um vidro com lã já apresenta esse problema. Seguindo seu raciocínio, o problema gira em torno da compressão dos poros. Um corpo que comprime mais seus poros quando atritado expulsa seu éter para dentro do outro. Logo, para sabermos qual corpo fica positivado, precisaríamos conhecer a estrutura porosa dos corpos em atrito. Isso não é fácil, e Johann Euler não tenta.

A solução encontrada pelo autor é estudar o caso do enxofre. Se derretermos e depois resfriarmos uma porção de enxofre, ela adquire um estado elétrico não-neutro que será oposto ao estado de um vidro polido excitado pelo atrito. A eletricidade no enxofre só aparece depois do resfriamento. Com isso, Johann Euler prossegue, o enxofre diminui de volume e, assim, seus poros também encolhem. Porém, esses poros mantêm a quantidade de éter que tinham antes do resfriamento, pois tratase de um isolante (corpo da primeira espécie, segundo 
o autor). Assim, a compressão sobre o éter e, por consequência, a sua elasticidade, aumentam. Como o aumento da elasticidade estava relacionado ao estado positivo, o vidro polido só pode estar no estado negativo; isso está em desacordo com a interpretação de Franklin. Por isso Johann Euler sugere inverter os estados elétricos como colocados por Franklin. Para reforçar esse argumento, Johann Euler ainda sugere um experimento, cujo resultado foi reportado por J. C. Wilcke. Nele, segundo Johann Euler, suas conclusões são reforçadas. Não conseguimos encontrar essa inversão sendo defendida explicitamente em outros lugares, porém ela aparece implicitamente em cartas de Leonhard Euler, seu pai.

Em uma curta carta de 21 de julho de 1761 a uma princesa da Alemanha ${ }^{19}$ Leonhard Euler analisa a definição de estados elétricos. Ele afirma que a maneira correta de averiguar se um corpo está com a eletricidade positiva ou negativa é analisando o surgimento de uma faísca entre um pedaço de um material (como uma barra) e o dedo de uma pessoa. Se a barra estiver positiva e alguém aproxima um dedo em uma extremidade da barra, a luz que sai da barra aparecerá sob uma forma bastante difusa, e um ponto luminoso aparecerá perto do dedo. Mas, se a barra estiver negativa, o ponto luminoso estará mais perto da barra. Para Leonhard Euler, a definição de estado positivo dependia de um aumento da elasticidade do éter em um corpo, assim como para Johann Euler. Uma queda da elasticidade define o estado negativo, tanto para Leonhard Euler quanto para seu filho mais velho [34, p. 284-287].

Em conclusão, no trabalho de Johann Euler, o vidro polido se tornava negativo, e o enxofre, positivo. $\mathrm{Na}$ carta de Leonhard Euler, o enxofre se torna negativo. Porém, essa diferença de resultado pode ser explicada devido às diferentes técnicas de eletrização empregadas. O pai atritou o enxofre, enquanto o filho o derreteu para depois resfriá-lo. ${ }^{20}$ Nesse sentido, em uma carta de 1 de agosto de 1761, Leonhard Euler discute a eletrização do enxofre depois de derretido e resfriado. Nesse caso, para ele, o enxofre fica positivo [34, p. 296-300], o que estava de acordo com o obtido por seu filho, porém com uma pequena diferença. Leonhard Euler entende que, no aquecimento, os poros do enxofrem abrem de tal forma que acabam recebendo "uma maior quantidade de éter para preenchê-los" [34, p. 299]. Johann Euler não é claro nesse ponto e apenas afirma que "o enxofre derretido não mostra nenhum traço de eletricidade ainda; ela só se manifesta após o resfriamento" 15

\footnotetext{
19 A princesa era Friedericke Leopoldine Louise Charlotte von Brandenburg-Schwedt (1745-1808) da linhagem BrandenburgSchwedt da família real Prussiana. Para mais sobre ela e sobre essas cartas, ver: 35 .

20 Johann Euler parece estar ciente de que o enxofre nem sempre ficará positivo. No último parágrafo de seu trabalho aqu traduzido, ele nota que se atritarmos chumbo contra o enxofre, este termina negativo, e não positivo. Ele parece entender que a eletrização por atrito depende dos dois corpos atritados 15 p. 158-159]. Então, supomos que ele está ciente que diferentes técnicas de eletrização podem levar a diferentes estados elétricos.
}

p. 156]. Nenhuma dessas frases e afirmações justificam o que o historiador John L. Heilbron afirma quando escreve que

os Eulers [Johann e Leonhard Euler] pensaram primeiramente que seu modelo requeria a inversão dos estados de Franklin, fazendo o vidro polido carregado negativamente pela fricção [Heilbron cita o trabalho de Johann Euler de 1759, páginas 156-158], mas depois eles aceitaram os argumentos usuais baseados no aparecimento de faíscas [Heilbron cita a carta de 21 de julho de 1761 de Leonhard Euler]. [2, p. 393; itálicos no original]

As referências citadas no trecho são justamente as mesmas que usamos aqui. Podemos ver que Heilbron se confundiu. Leonhard Euler afirmou que o enxofre fica negativo, mas o método de eletrização era diferente. Quando ele se debruça sobre o aquecimento e resfriamento, o estado elétrico do enxofre é positivo, como no trabalho de Johann Euler.

\section{Elasticidade ou Pressão: Sobre as Propriedades Fundamentais do Éter}

Paralelamente a essa discussão está o conceito de elasticidade. Matematicamente, a elasticidade é diretamente proporcional à densidade, como dito em vários trechos do Recherches Sur la Cause Physique de l'Electricité. Porém, conceitualmente, é difícil entender a elasticidade. Ela não é equivalente à densidade. Por exemplo, na equação (9), que é a principal fonte de suas explicações, quando elas se baseiam nas suas contas, a elasticidade do éter funciona como uma pressão. Pois, uma diferença na elasticidade do éter entre duas regiões do espaço gera uma força, que empurra os objetos para longe ou para perto de si. Assim, o conceito de elasticidade está mais próximo do conceito atual de pressão. Em um trecho, no parágrafo 33 , ele parece igualar os dois conceitos ${ }^{21} \mathrm{O}$ historiador John L. Heilbron também iguala elasticidade e pressão quando comenta sobre o trabalho de Johann Euler [2, p. 394].

Essa equivalência conceitual está alinhada a um trabalho escrito em 1753, e publicado em 1757, por seu pai sobre o equilíbrio dos fluidos. Nele, Leonhard Euler afirma que em um fluido compressível, a elasticidade depende da densidade, mas que ela não precisa seguir a densidade em uma razão constante (i.e., relação linear) em todos os casos. Mesmo assim, essa relação pode, em algumas condições, ser aproximados por uma relação linear [36, p. 224-225], o que é justamente o que Johann

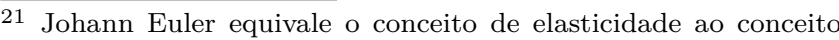
de pressão da época. Para nós, aquele conceito de pressão já estava próximo do atual conceito de pressão dentro de um fluido. Esse desenvolvimento foi muito beneficiado por Isaac Newton e Leonhard Euler [37. p. 166-171].
} 
Euler faz. Como essa parte do argumento não fica clara em Johann Euler, o leitor pode acabar confuso sobre a relação conceitual entre elasticidade e densidade. Mesmo assim, quando Johann Euler discute a eletrização por atrito, o éter flui de um corpo para outro e, nesse caso, a elasticidade parece uma medição da quantidade de éter que se move; como uma densidade de corrente de éter (ou um fluxo de éter).

Ademais, a palavra usada por Johann Euler é élasticité. Porém, em alguns momentos ele usa a palavra ressort com o mesmo significado. Ressort é uma palavra mais próxima da nossa palavra "mola". Uma mola é definida como elástica, então os conceitos são próximos, mas "mola" tem um sentido mais mecânico e tangível que "elasticidade". Nós traduzimos ambas as palavras por elasticidade, pois o contexto em que são usadas nos permite. Assim, pode-se observar que o autor pensa no éter (ou em seus constituintes) como podendo ser tensionado e esticado. Nesse caso, as ideias de Johann Euler remetem às ideias do russo Mikhail Vasil'evich Lomonosov (1711-1765) sobre a natureza da luz e da eletricidade, baseadas no movimento de vibração e rotação das partículas do éter. Estas influenciaram seu pai, Leonhard Euler, quando ele estava em São Petersburgo [2, p. 391-393]. Além disso, o uso da palavra ressort indica uma possível similaridades entre o éter de Johann Euler e o ar em Robert Boyle (1627-1691), já que este usava a expressão "spring of air", que em português é "mola do ar" (isso é discutido na nota de rodapé 49 da tradução comentada).

\section{A Repercussão Dos Trabalhos Sobre Eletricidade de Johann Euler}

Como apontamos ao longo deste texto, os artigos de Johann Euler trazem uma nova forma de encarar os fenômenos eletrostáticos básicos ao apresentarem uma interpretação mecânica detalhada apoiada em conceitos hidrodinâmicos e por trazerem uma abordagem matemática para eles. Apesar da sua originalidade, os trabalhos receberam pouca atenção na época. Isso pode ser atribuído aos fatos de não terem se aprofundado no fenômeno da garrafa de Leiden (o choque), que passou a ser central para os estudos elétricos a partir de 1746 ; e pela rede de contatos de Euler.

Johann Euler estava afastado dos dois principais círculos acadêmicos que estudavam eletricidade da época - Londres e Paris - e, assim, teria dificuldades para circular suas ideias. Dessa forma, filósofos naturais como Nollet, Sigaud de la Fond (1730-1810), Coulomb, John Canton (1718-1772) e Benjamin Wilson (17211788) provavelmente teriam dificuldade em encontrar cópias de seu trabalho. A título de exemplo, apenas o primeiro trabalho de Johann Euler, de 1754, é citado por Joseph Priestley (1733-1804) em seu famoso History and Present State of Electricity, na seção de catálogos de obras sobre o assunto no final do livro. Priestley coloca um asterisco nos trabalhos que usou para escrever seu livro, como os de Franklin, Nollet e Aepinus, mas não no de Johann Euler [38, p. iii].

\section{Comentários Finais}

A predominância da interpretação das interações como fruto de forças agindo à distância ao longo do século XVIII, que começou nos estudos sobre gravitação de Newton, e influenciou estudos em eletricidade em obras como as de Franz Aepinus e Charles-Augustin Coulomb representou uma mudança nos critérios pelos quais se podia entender o mundo 39. No contexto científico do século XVIII, a obra de Johann Euler, que pode ser chamado de mecanicista, pois explica as interações baseando-se na existência de forças tangíveis e de contato é um exemplo da possibilidade de se matematizar teorias elétricas de caráter mecanicista - a matematização não era restrita às teorias newtonianas.

O debate sobre qual seria a melhor forma de entender o mundo, seja por forças à distância, seja pela existência de um éter (e entidades mecanicistas), adentra o século XIX e influencia o desenvolvimento do eletromagnetismo ${ }^{22}$ e da relatividade 40 . Nesse sentido, o trabalho de Johann Euler pode ser visto no enquadramento de uma questão que, hoje já relegada à história da física, foi bastante central no passado.

\section{Comentários Sobre a Tradução}

A publicação aqui traduzida é de 1759, mas o trabalho de Euler foi apresentado em 1757 à Academia Real de Ciências de Berlim. O trabalho de Johann Euler aparece na seção de filosofia experimental. No texto original, Johann Euler não faz uso de notas de rodapé, então todas as notas da tradução são de nossa autoria, assim como as palavras em colchetes. Elas foram usadas para clarificar trechos confusos, melhorar a redação da tradução, apresentar em detalhes momentos do texto original que não são claros e contextualizar afirmações do autor original. Os parágrafos da tradução seguem a divisão do original, tanto os enumerados quanto os não-enumerados. As páginas do original foram marcadas com quebras de linhas, o número delas encontra-se em colchetes.

Aqui vale uma reflexão sobre a tradução da palavra électrique. Na época havia dois tipos de categoria para os corpos, elétricos per se e não-elétricos. Mas, quando Johann Euler usa a palavra électrique, é possível deduzir pelo contexto que seu uso se assemelha à palavra "eletrizado" na maioria das vezes, e não a uma categoria para os corpos. Por isso, optamos por traduzir électrique como "eletrizado". No $43^{\circ}$ parágrafo enumerado, o próprio

22 Para citar um trabalho nesse debate no século XIX, pode-se consultar a seguinte tradução de uma obra de Oliver Heaviside (1850-1925) sobre o assunto: 41. 
Johann Euler comenta sobre essa confusão envolvendo a referida palavra, afirmando que abandonará as categorias mencionadas "para evitar toda confusão que seria a temer dessas denominações" [15, p. 149]. Ele conclui que "as espécies [de corpos] estabelecidas são mais apropriadas para marcar essa distinção [da capacidade de ser eletrizado], sem deixar o menor equívoco." [15, p. 150].

A palavra "elasticidade" foi usada para traduzir élasticité. Porém, em alguns momentos Johann Euler usa a palavra ressort. Traduzimos as duas como "elasticidade". Na seção 6 acima detalhamos o motivo da escolha.

\section{Agradecimentos}

Agradecemos a Vitor José Leite Barbosa por sua valiosa ajuda na tradução do original, a Uirá Noberto Matos de Almeida, que nos auxiliou na análise das equações diferenciais parciais. Agradecemos também a CAPES pelo auxílio financeiro, ao $\mathrm{CNPq}$ pela bolsa de pesquisa \# 312748/2018-3 e aos comentários dos pareceristas.

\section{Tradução Comentada}

[p. 125]

Pesquisas sobre a causa física da eletricidade.

Por Sr. Euler, o filho.

Desde que eu dei minha explicação sobre a eletricidade, que a Academia Imperial de Petersburgo quisera coroar com o prêmio proposto sobre essa questão, descobriram-se vários novos fenômenos elétricos que pareciam derrubar minha teoria. Sr. Aepinus tendo mostrado claramente a diferença entre duas espécies de eletricidade, na qual uma recebe o nome de positiva e a outra de negativa, eu sou obrigado a confessar francamente que não havia prestado atenção nessa diferença. Embora Sr. Francklin ${ }^{23}$ e outros tenham já falado sobre isso enfaticamente, eu havia visto essa questão como algo pouco essencial, sobretudo porque a maioria dos Autores as conectaram a certos tipos de corpos, segundo os quais eles nomearam uma eletricidade vítrea e outra resinosa. Essa circunstância [vítrea e resinosa] me levou a acreditar que toda a diferença dependia unicamente da natureza dos corpos, sendo uma e outra espécie de eletricidade própria a cada corpo ${ }^{24}$

Mas, depois que foi suficientemente provado pelas experiências que o mesmo corpo é suscetível a uma

\footnotetext{
23 Johann Euler escreve Francklin referindo-se a Benjamin Franklin. O nome de Benjamin Franklin aparecerá escrito dessa forma por todo o trabalho, assim tomamos a liberdade de não chamar a atenção a isso todas as vezes por meio de notas de rodapé. O uso de itálico na tradução segue o do original.

24 Aqui, Johann Euler parece enxergar as eletricidades vítrea e resinosa, idealizadas pelo francês Charles François de Cisternay Dufay no começo do século XVIII, como explicações qualitativas que o induziram a uma explicação errônea dos fenômenos elétricos.
}

ou outra espécie, e mesmo algumas vezes às duas ao mesmo tempo em suas diferentes partes ${ }^{25}$ eu devo convir que minha explicação é consideravelmente abalada. Pois, tendo sustentado que um corpo só era eletrizado à medida que o éter nele contido era mais raro e menos elástico do que aquele que se encontra nos corpos vizinhos, toda a diferença na eletricidade só poderia vir dos diversos graus de escassez do éter contido dentro dos corpos elétricos; o que, entretanto,

[p. 126]

é abertamente contrária às experiências feitas sobre a eletricidade positiva e negativa, assim, dado que isso é evidente, a diferença não poderia ser atribuída a uma escassez maior ou menor de éter.

Mas, já que a minha explicação é embasada sobre a falta de equilíbrio do éter, segue-se que os fenômenos da eletricidade devem se manifestar em um corpo quando o éter se encontra mais denso ou mais elástico, e quando é mais raro e menos elástico do que nos corpos ao redor. Essa única observação nos desvela primeiro duas espécies de eletricidade, das quais uma será sem dúvida aquela que chamamos positiva, e outra aquela que chamamos negativa. E assim, longe da minha teoria ser derrubada por essa dupla eletricidade, ela adquire no fundo um maior grau de probabilidade. Essa dupla eletricidade é até mesmo uma consequência necessária da minha explicação, já que o éter não poderia ser rarefeito em um corpo sem que ele fosse condensado em outros.

Eis aqui, então, o princípio de minha teoria, que se reduz a seguinte proposição: Que os fenômenos da eletricidade são causados pela força elástica do éter, quando esse fluido não está em equilíbrio dentro dos corpos vizinhos. Isto é, quando o éter encerrado dentro dos poros dos corpos não está em equilíbrio, ou que sua elasticidade é maior ou menor em um [corpo] do que em outro, os esforços resultantes para restaurar o equilíbrio produzem os fenômenos da eletricidade. De modo que a causa desses fenômenos deve ser atribuída à desigualdade de elasticidade do éter que se encontra encerrado nos corpos. Para estabelecer essa teoria, deve-se primeiro fazer algumas observações sobre a natureza do éter e sobre a maneira em que ele está enclausurado nos poros dos corpos. Em seguida é necessário mostrar como a restauração do equilíbrio, quando a elasticidade do éter é diferente em diferentes corpos, é capaz de produzir os fenômenos da eletricidade.

I. Todos aqueles que se comprometem a explicar os efeitos da eletricidade concordam que a causa deve ser procurada em uma matéria

[p. 127]

sutil difundida em todos os corpos, a qual eles dão o nome de matéria elétrica. De acordo com alguns, é uma

\footnotetext{
25 Johann Euler se refere à explicação de Franklin para a garrafa de Leiden. Para mais detalhes sobre sua invenção, ver a referência $[2$ p. 309-343]. Além da referência 9].
} 
certa agitação excitada nessa matéria que produz os fenômenos da eletricidade 26 Ora, Sr. Francklin atribui essa causa a uma distribuição desigual da dita matéria, e defende que um corpo se torne eletrizado quando essa matéria se encontra em quantidade ou demasiadamente grande, ou pequena. Ele supõe que no estado natural a matéria elétrica é igualmente dispersa por todos os corpos, de modo que nesse estado cada corpo contém uma certa quantidade [de matéria elétrica]. Assim, se por algum motivo essa quantidade aumenta ou diminui, é então, segundo ele, que os corpos se tornam eletrizados. Disso ele tira a origem das duas espécies 27 de eletricidade, e acredita que aquela que ele nomeia positiva ocorre quando a matéria elétrica se encontra em quantidade demasiadamente grande, enquanto que a negativa vem de uma diminuição da matéria elétrica para baixo da quantidade natural.

II. Vê-se essa última circunstância como uma prova bastante sólida da realidade da ideia, a partir da qual Sr. Francklin imagina a causa da eletricidade. Também longe de mim querer derrubá-la, eu me proponho antes a determinar melhor a natureza e as propriedades dessa matéria que ele chama elétrica. De fato, como não se pode negar a existência do éter, que preenche todos os poros que o ar e outras matérias mais densa: ${ }^{28}$ deixam vazios. Será uma questão bem importante saber se a matéria elétrica é a mesma que o éter, ou se é diferente dele. E primeiro me parece que, a menos que não se possa demonstrar uma diferença bem marcada entre a matéria elétrica e o éter, as regras da probabilidade decidirão sempre pela sua identidade, e isso, mesmo que se quisesse recolocar em dúvida a existência do éter, o que poderia me impedir de impor esse nome à matéria elétrica, ainda que as provas pela existência do éter sejam, aliás, bem convincentes.

III. Contudo, alguns, que não negam abertamente a existência do éter, concebem a matéria elétrica de uma maneira tal

[p. 128]

que não poderia estar de acordo com as propriedades que Autore 29 atribuem ao éter. Eles entendem a matéria

\footnotetext{
26 Aqui Johann Euler pode estar fazendo referência à vários autores, entre eles do russo Mikhail Vasil'evich Lomonosov. Suas ideias sobre a natureza da luz e da eletricidade, baseadas no movimento das partículas do éter, influenciaram seu pai, Leonhard Euler [2] p. 391-393]. Isso foi citado na seção 6, quando discutimos sobre o conceito de elasticidade.

27 Johann Euler se refere aos estados de Franklin como "espécies". O mais correto com as ideias de Franklin é "estado" elétrico, e não "espécie".

28 No original: plus grossieres. No sentido de mais densas, ou também mais espessas.

29 Neste ponto Johann Euler cita genericamente autores que definiam um éter apenas para rechaçá-lo. Entre eles definitivamente está Franz Aepinus, que defendia um fluido elétrico para explicar os fenômenos elétricos e um fluido magnético para os magnéticos. Aepinus, que trabalhou na Academia de Ciências de Berlim entre 1755 e 1757 e conheceu Leonhard e Johann Euler, critica a junção deles em um único fluido, "a saber, um éter" [14 p. 243], pois os fenômenos nesses dois casos eram muito diferentes.
}

elétrica como uma atmosfera, que envelopa os corpos 30 mas tanto a violência dos efeitos elétricos, quanto a sua rapidez, parecem, em primeira análise, destruir a ideia de uma atmosfera, em qualquer agitaçã ${ }^{31}$ que se queira concebê-la. Os fenômenos da eletricidade provam antes, incontestavelmente, que a matéria sutil que os produz deve ser dotada de um grau eminente de elasticidade, que não poderia ser enclausurada dentro dos limites de uma pequena atmosfera. Aliás, as faíscas e os brilhos luminosos, de que esses fenômenos são frequentemente acompanhados, demonstram suficientemente que sua causa é bem estreitamente ligada àquela que produz a luz, e que é, seguramente, muito mais ativa do que tudo que se poderia entender sob a ideia de uma atmosfera.

IV. Eu não me limitarei a estabelecer a existência do éter, que só foi posta em dúvida pelos Filósofos que queriam esvaziar o espaço dos Céus de toda a matéria, de medo que os Planetas e Cometas encontrassem aí alguma ${ }^{32}$ resistência em seus movimentos. Mas, sendo esses mesmos filósofos obrigados a preencher o imenso espaço do Mundo de raios de luz, que eles veem como emanações próprias dos corpos luminosos, lançados com a mais alta velocidade, em vez de um vazio, eles nos apresentam um espaço perfeitamente preenchido de uma matéria agitada pelo mais impetuoso movimento que se possa conceber. Uma tal matéria deveria, sem dúvida, perturbar extremamente os movimentos dos corpos celestes se uma matéria similar e tranquila fosse capaz de causar-lhes uma resistência sensível.

V. Por essa razão, aliada a várias outras que eu me permito não expor aqui, eu me considero bem autorizado a supor tanto o espaço imenso dos Céus quanto todos os poros terrestres preenchidos por uma matéria extremamente sutil e elástica, na qual os raios de luz são

30 Johann Euler se refere ao conceito de atmosfera elétrica proposta por Franklin. Para mais, ver 4.

31 No original a palavra é agitation. Aqui ela pode significar também "vibração" ou "movimento".

32 Entre os filósofos que explicitavam que alguma resistência seria encontrada pelos planetas caso houvesse uma matéria estava Isaac Newton. Para Newton, a regularidade do movimento dos planetas era um indicativo de que tal matéria não existia [3, p. 32]. A resposta de Johann Euler lembra a de seu pai, Leonhard Euler, de 1746, que apontou a contradição de se aceitar a existência de partículas de luz no espaço [3, p. 81-82]. Leonhard Euler chega a calcular, usando sua teoria etérea, que a resistência do éter não é observável para uma rarefação de éter (inverso da densidade) maior ou igual a $3875 \times 10^{8}$ [3. p. 130], o que explicaria as observações astronômicas. Porém, Newton nunca associou a falta de um éter no espaço ao vácuo absoluto da forma como Leonhard Euler descreveu. Nos Principia Newton afirma que "os espaços celestiais (...) devem ser totalmente livres de quaisquer fluidos corpóreos", mas ressalta que "excetuando, talvez, alguns vapores extremamente rarefeitos e os raios de luz" [42, p. 147]. Quando Newton postula e utiliza a ação à distância, ele se afasta de trabalhos etéreos por motivos mais pragmáticos, não por desacreditá-los por completo (ou refutá-lo) [24 p. 80-89]. 
produzidos por um movimento de vibração parecido com aquele do qual sabemos que o som é produzido no ar ${ }^{33} \mathrm{E}$ [p. 129] mesmo pela velocidade da luz comparada à do som 34 que podemos determinar a elasticidade do éter aliada a sua rarefação porque, se o éter é $m$ vezes mais rarefeito e $n$ vezes mais elástico que o ar ordinário que respiramos, é necessário que o produto desses dois números, $n$ e $m$, seja igual a trezentos e sessenta bilhões ${ }^{35}$ donde compreendemos facilmente que um deles ${ }^{36}$ ser extremamente grande.

VI. Ora, se todos os poros dos corpos e todos os espaços nos quais matérias mais grossas não poderiam penetrar são repletos de éter, a menos que a matéria elétrica seja a mesma, somos obrigados a preencher os poros de duas matérias diferentes e de

33 Desde o século VI já se afirmava que o som podia ser um produto de vibrações de corpos. Isaac Beeckman (1588-1637) também trabalhou com a relação entre vibrações e o som. Essa relação pode ser vista na obra Diálogo de Galileu Galilei (15641642) e Dissertatio physica de sono, de Leonhard Euler. Para mais, ver: 43

34 A velocidade do som no ar já havia sido medida no século XVII, resultando em um valor de $478,4 \mathrm{~m} / \mathrm{s}$ em 1635 . Esse valor foi se aproximando do atual $(331,45 \mathrm{~m} / \mathrm{s}$, aproximadamente) ao longo do fim do século XVII e começo do século XVIII [43, p. 635], ou seja, antes do trabalho aqui traduzido.

35 Nesta passagem, Johann Euler compara as velocidades de propagação da luz com a do som. Considerando $m$ a rarefação do éter em relação a do ar, e $n$ a elasticidade do éter em relação a do ar, afirma que o produto das duas grandezas deve ser igual a 360 bilhões, sem unidades dimensionais. Seu raciocínio não é claro, mas como ele estava comparando a velocidade do som no ar com a velocidade da luz, podemos supor que ele estava utilizando resultados obtidos anteriormente por seu pai que em 1746 publicou o trabalho sobre ótica conhecido como Nova Theoria Lucis et Colorum Nesse trabalho, Leonhard Euler desenvolveu uma teoria etérea para a luz [44. No capítulo 2, ao discutir a propagação de um pulso de éter deduz que a velocidade do pulso, $v$, é igual a $\sqrt{E / D}$, onde $E$ é a elasticidade do éter, e $D$ é a densidade do éter 3 p. 94]. Para realizar esses cálculos, ele baseia-se no tratamento dado por Isaac Newton para meios elásticos, particularmente o ar [3. p. 92]. Leonhard Euler considera, então, a rarefação do éter em relação ao ar como $m$, e a elasticidade do éter em relação ao ar como $n$,

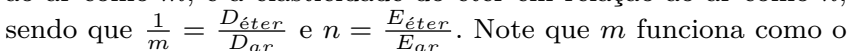
inverso da densidade. Assim, Leonhard Euler obtém, em notação moderna $m n=\left(\frac{v_{l u z}}{v_{\text {som }}}\right)^{2}$. Com os valores que Euler tem para as duas velocidades, tem-se $m n=387.467 .100 .000$, implicando em um valor para a velocidade da luz como aproximadamente 622.000 vezes maior que a do som (mantivemos a notação do original 44, p. 195], haja vista que ela é igual a notação usada por Johann Euler). Ele provavelmente aproximara 622.000 para 600.000, obtendo assim $m n=360.000 .000 .000$. Logo, apesar de não sabermos com total confiança se Johann Euler referia-se ao trabalho de seu pai, supomos que sim, pois conseguimos recuperar o valor de 360 bilhões. Este valor também aparece no seu primeiro trabalho sobre eletricidade (publicado em 1757), sendo seu único uso da matemática naquela obra 45 .

${ }^{36}$ A frase original é: (...) que l'un Eु l'autre doit être extrèmement grand. O verbo está conjugado incorretamente, deveria ser doivent, a não ser que ele quisesse dizer l'un ou l'autre ("um ou outro", em português). O segundo sentido, isto é, com doivent, parece mais correto matematicamente, dado que basta que um dos dois números seja grande (e o outro não seja zero, ou infinitesimal), para que sua análise esteja correta. Os dois não precisam ser grandes simultaneamente. atribuir-lhes propriedades também diferentes. Mas parece, em princípio, contrário às regras de uma boa Física multiplicar a bel prazer as matérias sutis; e deveríamos ter provado incontestavelmente que o próprio éter não seria absolutamente capaz de produzir os fenômenos da eletricidade antes de recorrer ao expediente de criar uma nova matéria sutil. Mas a violência e a rapidez desses fenômenos, e principalmente a produção de faíscas e brilhos luminosos, convêm tão bem à natureza do éter, que não há nenhuma razão para abandoná-lo.

VII. Embora o éter em seu estado natural tenha um grau determinado de elasticidade, é entretanto possível aumentá-lo ou diminuí-lo. Isso é claro mesmo pela produção da luz, que consiste em um movimento de vibração, cuja natureza exige absolutamente diferentes graus de elasticidade nas partes próximas ao éter. Ademais, não poderíamos formular uma ideia correta de sua elasticidade sem supô-lo suscetível a uma maior ou menor compressão. Ora, é muito natural que aumentando ou diminuindo a sua densidade, sua elasticidade deve receber acréscimos ou decréscimos mais ou menos proporcionais, como acontece com o ar, com o qual o éter tem pelo menos isto em comum: um e outro são compressíveis e elásticos, ainda que a elasticidade do éter seja incomparavelmente

[p. 130]

maior que a do ar, bem como sua densidade é incomparavelmente menor.

VIII. O éter preenchendo, então, todo o espaço do mundo no qual os corpos celestes completam seus movimentos, não há nenhuma dúvida de que ele se insinua nos menores poros de todos os corpos e que ele os preenche. A extrema sutilidade e elasticidade o tornam bem propício a esse efeito. O próprio ar, sendo em relação ao éter uma matéria mais densa, não deixará de conter uma boa quantidade [de éter] entre partículas [do ar] que lhe são próprias. E talvez esse éter esteja enclausurado, donde a elasticidade do ar tira a sua origem. Talvez ainda todos os outros corpos dotados de elasticidade devem essa qualidade ao éter, que se encontra enclausurado em seus poros. Essa explicação da elasticidade de todos os corpos é incontestavelmente a mais natural, ainda que ela não leve de jeito nenhum à fonte primeira, ou seja, a causa da elasticidade do próprio éter. Mas somos obrigados, tanto na Física quanto nos outros objetos de nossos conhecimentos, a renunciar ao conhecimento das causas primeiras.

IX. Entretanto, por mais sutil que possa ser o éter, não se deve imaginar que ele penetre livremente nos poros de todos os corpos, nem que a comunicação com o éter externo, ou daquele que se encontra nos poros dos corpos vizinhos, seja inteiramente aberta. Porque, se o éter é a causa da elasticidade dos corpos, compreende-se facilmente que esse efeito [a dificuldade de comunicação do éter] não poderia resultar disso [da elasticidade do éter] a menos que ele esteja bem enclausurado nos poros dos corpos e que ele possa ser comprimido sem relaxar 
imediatamente e retomar o seu estado natural. Várias experiências sobre o vácuo, e sobre os brilhos luminosos que o mercúrio lança quando agitado 37 provam suficientemente que o éter não encontra uma passagem totalmente livre através do vidro.

X. Este artigo, no qual é principalmente fundada minha Teoria da eletricidade ${ }^{38}$ merece que eu me prolongue mais cuidadosamente. Observo aqui um barômetro luminoso, cujo alto acima do mercúrio

[p. 131]

é sem dúvida ocupado pelo éter. Inclinando o tubo, de maneira que o mercúrio o preencha completamente, o éter é expulso e escapará, ou pelo vidro, ou para dentro dos poros do mercúrio, expulsando ou comprimido ainda mais o éter que já os ocupava. Agora, recolocando o tubo para reproduzir o vácuo acima do mercúrio, é necessário que o éter retorne [para onde estava], ou do exterior pelo vidro, ou dos poros do próprio mercúrio. Ora, os brilhos luminosos que vemos sair do mercúrio provam suficientemente que é do mercúrio que sai o éter e, já que ele é chacoalhado até produzir luz, é claro que seu movimento é impedido, assim como o movimento de ar comprimido dentro de um vaso, que é obrigado a sair por pequenos buracos. É necessário que o éter escape dos poros do mercúrio com grande rapidez, dos quais ele recebe um movimento de vibração, tal como é necessário para a produção da luz. Pode-se ver esse fenômeno análogo ao assovio que o ar comprimido produziria escapando por um pequeno buraco.

XI. Ora, se o éter penetrasse livremente todos os corpos, como vários Físicos defenderam, seduzidos sem dúvida pela extrema sutilidade desse fluido, não divergiríamos que o dito fenômeno nunca poderia acontecer, posto que o éter entraria no vácuo desde o primeiro instante, tanto pelos poros do vidro quanto pelos do mercúrio, sem sofrer a mínima agitação. Esse restabelecimento ocorreria tão tranquilamente que o ar ocuparia os espaços que os corpos abandonam por seu movimento, ainda que esses espaços fossem envelopados por redes. É então necessário que o éter esteja bem estreitamente enclausurado e encaixado dentro dos poros do mercúrio, já que sua grande elasticidade não é capaz de expandi-ld ${ }^{39}$ em um instante pelo espaço vazio do tubo. Entretanto ele escapa muito prontamente, como os brilhos luminosos deixam saber, e vê-se que a passagem pelos poros do vidro deve ser muito mais difícil. Não é, portanto, contrário à natureza do éter quando eu suponho que esse fluido, por mais ágil que seja, não atrevesse livremente os corpos, e que há

\footnotetext{
37 O início do uso do barômetro em pesquisas elétricas data do início do século XVIII e pode ser visto com detalhes em: 46].

38 Portanto, Johann Euler vê este texto como a fundação de sua teoria, e não o de 1754, enviado à Academia de São Petersburgo.

39 Johann Euler escreve le répandre, que entendemos aqui como "expandi-lo", não fica claro quem está expandindo, o éter ou o mercúrio. Por força do contexto, inferimos que ele esteja se referindo ao éter.
}

\section{[p. 132]}

a esse respeito uma grande diferença: uns, muito mais do que outros, retendo o éter que está enclausurado em seus poros e talvez não haja nenhum que permita a seu éter uma saída totalmente livre, como provavelmente também não há nenhum que o mantenha tão fortemente cerrado que ele [o éter] não possa, em absoluto, escapar.

XII. Tendo estabelecido essa diversidade nos corpos, segundo a qual o éter se encontra mais ou menos encerrado, noto primeiro que o ar deve ser relacionado a essa espécie que retém seu éter muito fortemente, de modo que ele quase não poderia escapar. Porque, já que praticamente não se encontra corpos cuja elasticidade seja tão perfeita, se o éter encerrado nos poros do ar é a causa [da elasticidade do ar], é necessário que ele esteja bem estreitamente encaixado, de modo que ele possa ser comprimido com o ar, sem que uma parte considerável [do éter] encontre meio de se relaxar ${ }^{40}$ Não considero essa prova totalmente convincente, mas me gabo que ninguém oporá dificuldade em concordar comigo acerca dessa propriedade do ar quando mostrarei que ela é absolutamente necessária para a explicação dos fenômenos da eletricidade. Aliás, qualquer outra matéria elétrica que se queira estabelecer, seremos sempre obrigados a supô-la bem intimamente encaixada nos poros do ar. E quando não se coloca dificuldade para atribuir essa propriedade a uma outra matéria, talvez puramente imaginária, não poderíamos recusá-la ao éter.

XIII. Se o éter enclausurado dentro dos poros dos corpos fosse, em todo canto, dotado do mesmo grau de elasticidade, ele se encontraria em um perfeito equilíbrio, e não faria nenhum esforço de sair de um [corpo] para entrar em um outro, o que nomearei estado natural dos corpos para distingui-lo do estado elétrico, que resulta quando a elasticidade do éter enclausurado dentro dos poros dos corpos vizinhos não é a mesma. Vê-se bem que a maior ou menor conexão do éter com os poros dos corpos não tem nenhuma influência sobre o estado natural. E que seria a mesma coisa quer o éter fosse inteiramente envelopado de modo a não poder escapar de maneira alguma, ou que pudesse sair livremente.

[p. 133]

Mas, se todos os poros dos corpos fossem completamente abertos, o estado elétrico não poderia nunca acontecer, já que à menor desigualdade na elasticidade do éter desde o primeiro instante, o equilíbrio seria prontamente restabelecido. E se, por alguma causa qualquer, uma desigualdade considerável tivesse sido causada, ela seria retificada imediatamente pela comunicação livre do éter de todas as partes. O estado elétrico seria igualmente excluído se os poros dos corpos estivessem tão bloqueados que toda a comunicação do éter seria interrompida.

\footnotetext{
40 Esse argumento só faz sentido se adicionarmos depois do verbo "relaxar" uma ponderação como: "em outra direção que não a pressionada". Ou seja, que o éter não consiga, de imediato, escapar para outra direção e, assim, dificultando a elasticidade do ar, já conhecida desde os experimentos sobre o vácuo no século anterior [47, p. 44-45].
} 
XIV. Daí é claro que o estado elétrico exige duas condições absolutamente necessárias à sua produção. Uma é que o éter enclausurado em diferentes corpos se encontre em diferentes graus de elasticidade, e a outra é que os poros dos corpos que contêm o éter não sejam, nem completamente abertos, nem completamente bloqueados. Parece muito que não há nenhum corpo que pertença a uma ou outra dessas duas extremidades e, partindo disso, todos os corpos serão propícios a se tornarem eletrizados. Poderia mesmo bastar que um dos dois corpos tivesse seus poros retraídos para bloquear seu éter, enquanto que o outro tivesse seus poros completamente abertos. Este último caso parece acontecer dentro do vácuo artificial que se produz pela máquina pneumática, porque, tendo retirado todo o ar, não haverá nada exceto o puro éter ocupando o espaço. O mesmo se dá com o vácuo formado acima do mercúrio nos barômetros, fazendo-se com que essas espécies de vácuo forneçam fenômenos totalmente particulares da eletricidade.

XV. Essas duas condições podem produzir uma variedade infinita de fenômenos elétricos, conforme a diferença entre os graus de elasticidade do éter seja maior ou menor e, que os poros dos corpos retenham mais ou menos o éter. Em relação à primeira condição, a outra continuando igual, os efeitos da eletricidade serão ainda mais violentos conforme a desigualdade será maior entre os graus da elasticidade do éter. Mas, em relação à segunda condição, não é tão fácil prever qual diferença deve produzir uma comunicação mais ou menos

[p. 134]

livre do éter enclausurado em diferentes corpos. É necessário aqui, sobretudo, considerar a natureza do meio que se encontra entre os dois corpos: se é um ar seco, que mantém o éter fortemente enclausurado em seu seio, os fenômenos devem ser bem diferentes de quando é um ar úmido, já que a água pela qual o ar está embebido é uma dessas matérias que concedem ao éter uma fluidez bem livre.

XVI. Após essas observações gerais, consideremos um único corpo situado no ar, ou em outro meio qualquer, onde o éter se encontra no seu estado natural. Agora esse corpo será eletrizado quando o éter enclausurado em seus poros terá uma elasticidade maior ou menor que a natural: esses dois casos conduzem primeiramente às duas espécies de eletricidade, a positiva e a negativa. Mas não se saberia ainda definir qual corresponde a cada uma, os fenômenos de um caso e de outro se parecem tanto que é muito difícil concluir quando a elasticidade do éter no corpo é maior ou menor do que a do éter exterior. As diversas operações pelas quais a eletricidade é excitada fornecerão os meios mais seguros de nos esclarecer sobre essa dúvida porque, examinando bem todas as circunstâncias de que cada operação é acompanhada, deixará de ser difícil julgar se o éter é comprimido ou rarefeito. Mas, já que esse exame demanda pesquisas muito complicadas, será bom adiá-ld 41 até que eu tenha considerado os fenômenos mais simples e me será permitido supor aqui corpos eletrizados, sem mais me preocupar com a maneira pela qual eles se tornaram eletrizados.

XVII. Como quer que seja, a natureza dos termos positivo e negativo exige que nomeemos positivamente eletrizados os corpos nos quais o éter é comprimido ou reduzido a um grau mais alto de elasticidade, do que em seu estado natural, e eu nomearei negativamente eletrizados os corpos nos quais a elasticidade do éter é menor. Acredito que estou autorizado a essa determinação pelo próprio significado dos termos, e ainda que Sr. Francklin tivesse servido-se de uma explicação

[p. 135]

oposta e que tivesse empregado os termos positivo e negativo no significado contrário, não creio que sua autoridade devesse prevalecer sobre o significado natural. Enquanto estamos nessa incerteza, conservemos antes a distinção da eletricidade usada anteriormente, a saber vítrea e resinosa, sem decidir qual deve ser chamada positiva ou negativa ${ }^{42}$

XVIII. Eu começo então pelo caso mais simples, supondo um corpo eletrizado colocado em um meio de sorte que não tenha nenhuma comunicação com qualquer outro corpo. Se o éter enclausurado nos poros desse corpo for mais ou menos elástico ${ }^{43}$ que o do meio, é necessário que o equilíbrio seja enfim restabelecido, e isso ainda mais prontamente segundo que os poros tanto do corpo quanto do meio estiverem mais abertos para facilitar mais a comunicação: se o corpo se encontrasse num espaço vazio, ou no éter puro, o equilíbrio deveria ser logo restabelecido, a menos que os poros do corpo estivessem quase inteiramente bloqueados. Porque, já que todos os poros na superfície desembocam no éter livre, o equilíbrio ali logo se dará, e daí a comunicação passará para o interior do corpo. Os fenômenos poderão ser bem diferentes conforme a comunicação se faça mais ou menos livremente.

XIX. Mas a determinação do próprio movimento, que será excitado no éter, depende, de um lado, de um conhecimento perfeito dos fluidos em geral, e em particular dos fluidos elásticos, de que ainda estamos bem longe, de outro lado, deveríamos conhecer a figura dos poros, sua amplitude e sua comunicação. Ora, todas essas circunstâncias nos são tão ocultas que nunca poderíamos esperar obter seu conhecimento. Entretanto, é disso que depende a elasticidade do éter durante sua agitação, assim a pressão [criada pelo éter] que o corpo sustenta de toda parte não sendo igual em todo canto, o próprio corpo será solicitado ao movimento ${ }^{44}$ como vemos que

41 Johann Euler voltará a essa questão a partir do parágrafo LI. 42 As denominações vítrea e resinosa surgiram no trabalho de Charles Dufay. Para mais, ver: 21.

43 No original: Élastique. Aqui fica claro que o termo "elástico" refere-se não à propriedade de elasticidade, mas a quantidade que se contrai ou estica no éter (em alguma região do espaço).

44 Johann Euler argumenta que os princípios da dinâmica de fluidos elásticos e as propriedades dos poros explicam as diferenças 
de fato ocorre no encontro dos corpos eletrizados, que parecem ora se atrair, ora se repelir mutuamente.

[p. 136]

Donde se julgará facilmente que a explicação desses fenômenos de atração e de repulsão é a mais difícil, visto que ela demanda as mais sublimes pesquisas sobre o movimento dos fluidos e, além disso, um perfeito conhecimento da estrutura dos corpos, o qual o espírito humano nunca poderia alcançar.

XX. Entretanto, esforçar-me-ei em traçar alguns esclarecimentos, por mais fracos que possam ser, a fim de poder avaliar, grosso modo, fenômenos que daí devem resultar. Em vista disso, farei hipóteses um pouco grosseiras para nelas poder aplicar o cálculo, mas terei o cuidado de aproximá-las da verdade o quanto as circunstâncias me permitirão fazê-lo. Suporei então primeiro que a elasticidade do éter é proporcional à sua densidade, o que não se poderia pôr em dúvida vista a pequena mudança que a eletricidade pode produzir na densidade do éter. Em seguida, considerarei os poros tanto dos corpos quanto do ar como tubos de uma largura qualquer, pelos quais o éter se move livremente, e quando os corpos permitirem ao éter uma passagem mais ou menos livre, suporei esses tubos mais ou menos largos ${ }^{45}$ Porque é claro que tais tubos muito estreitos corresponderão aos corpos que deixam dificilmente escapar o éter neles enclausurado. Parece-me então que essas hipóteses não nos afastarão muito da verdade.

\section{46}

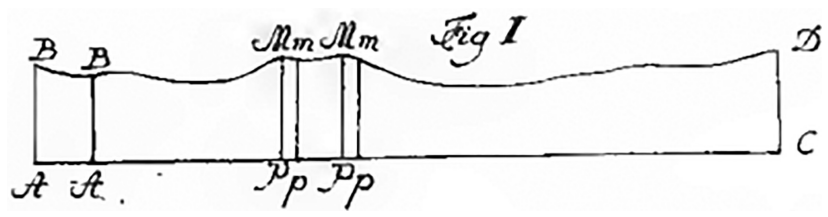

Seja então um tubo qualquer $\mathrm{ABCD}$ que se pode conceber como reto, já que a curvatura não influi significativamente no movimento [do éter] ${ }^{47}$ Seja a amplitude

de elasticidade do éter em regiões diferentes de um corpo (ou em seu redor). Essa diferença cria uma diferença de pressão. Em termos modernos, um gradiente de pressão não nulo. Este explica o movimento de um corpo submetido a diferenças de pressão no éter. No caso, os movimentos são justamente os de atração e repulsão causados pelos fenômenos elétricos.

45 Há várias suposições implícitas aqui, por exemplo, possíveis peneiras no interior do tubo, que poderiam dificultar o movimento do fluido elástico sem que a largura precisasse mudar (ou variar ao longo do tubo).

$46 \mathrm{Na}$ imagem, os 'A', 'B', ' $\mathrm{P}$ ' e ' $\mathrm{M}$ ' mais à direita deveriam estar com uma apóstrofe cada. Esse erro tipográfico se encontra na imagem original, a imagem corrigida é apresentada na introdução deste artigo. Além disso, no trabalho original as imagens se encontram no final do texto, como era comum na época. Porém, decidimos juntá-las aos trechos onde elas são citadas para facilitar o entendimento.

47 Não fica claro o motivo da curvatura não influenciar o movimento do éter. Se uma curvatura qualquer no tubo fosse aproximadamente $90^{\circ}$, um fluido teria sua velocidade ali claramente reduzida. desse tubo em $\mathrm{A}=f f{ }^{48}$ e a uma distância qualquer $\mathrm{AP}=$ $x$, a amplitude do tubo $\mathrm{PM}=y y$, que se pode considerar como uma função de $\mathrm{x}$. Seja então $d y=u d x$, onde a quantidade $u$ é também uma função de $x$. Agora, depois de decorrido um tempo qualquer $=t$, seja a densidade do éter em $\mathrm{AB}=\pi$ e em $\mathrm{PM}=\varphi$, donde a elasticidade tendo uma dada proporção à densidade, que seja $n: 149$ teremos a elasticidade em $\mathrm{AB}=n \pi$ e em $\mathrm{PM}=n \varphi$. Ora, a elasticidade é expressa por uma altura de [p. 137]

forma que $n \pi$ e $n \varphi$ representam linhas retas de um certo comprimento. Seja ainda a velocidade do éter na seção $\mathrm{AB}=\omega$, e na seção $\mathrm{PM}=\gamma \sqrt{50}$ Isso posto, as quantidades $\pi$ e $\omega$ serão funções do único tempo $t$. Ora, as quantidades $\varphi$ e $\gamma$ dependerão tanto do tempo $t$ quanto do espaço $\mathrm{AP}=x$, de modo que seus diferenciais, enquanto dependentes dessa dupla variabilidade, podem ser representados na forma:

$$
d \varphi=d t\left(\frac{d \varphi}{d t}\right)+d x\left(\frac{d \varphi}{d t}\right) \& d \gamma=d t\left(\frac{d \gamma}{d t}\right)+d x\left(\frac{d \gamma}{d x}\right) \square 1
$$

XXII. Tomando Pp $=d x$, o espaço PM $p m$ será $=y y d x$, e a densidade do éter ali presente $=\varphi$, a quantidade do éter contido nesse espaço elementar será $=\varphi y y d x$, e assim toda a quantidade do éter contida no tubo $\mathrm{ABPM}$ será $=\int \varphi y y d x$, considerando aqui $\varphi$ como uma função da única variável $x$, ou então deve-se tomar nessa integração o tempo $t$ como constante. Mas, após um tempo infinitamente pequeno $d t$, a primeira seção do éter $\mathrm{AB}$ passará para $\mathrm{A}^{\prime} \mathrm{B}^{\prime}$ sendo transportada pelo espaço $\mathrm{AA}^{\prime}=\omega d t$, e a seção $\mathrm{PM}$ para $\mathrm{PM}^{52}$ pelo espaço $\mathrm{PP}^{\prime}=\gamma d t$. A porção do éter que ocupava antes o espaço $\mathrm{ABA}^{\prime} \mathrm{B}^{\prime}$ é $=f f \pi \omega d t$, e a porção que ocupa 48 Uma notação comum à época para potências ao quadrado [4]
p. $349-350]$.
49 A notação para proporção aqui indica que, quando a densidade é
unitária, a elasticidade vale $n$. A notação era comum em divisões e
proporções na época 48 p. $271-278$ ]. Essa proporção é baseada no
raciocínio apresentado no parágrafo V, Johann Euler não adiciona
mais detalhes nesse ponto, mas ela se parece com uma afirmação
sobre o ar nos trabalhos de Robert Boyle, a saber, que a resistência
à compressão do ar é proporcional a sua densidade [49, p. $484-$
490 ]. Nesse caso, a resistência à compressão se parece com a
interpretação de Euler para a elasticidade do éter. A dependência
entre elasticidade e densidade de um fluido também aparece -
e é defendida, apesar de nem sempre se dar por uma relação
linear - em um trabalho sobre o equilíbrio dos fluidos de Leonhard
Euler [37, p. 224-225]. As similaridades entre o éter de Johann
Euler e o ar, em Boyle, esclarecem o uso da palavra "ressort".
Pois, Boyle usava muito a expressão "spring of air" (mola do ar) e
"ressort" é uma palavra francesa próxima da nossa palavra "mola".
50 Escolhemos o uso da letra gama, pois não encontramos o
caractere usado por Johann Euler. No original, a letra para a

velocidade do éter na seção PM é:

51 As derivadas encerradas por parênteses eram uma notação comum para o que denotamos hoje como derivadas parciais [50 p. 220-222]. Elas são usadas em todo o texto de Johann Euler. Para esclarecer podemos escrever essa equação em notação atual, o que nos retorna: $d \varphi=d t\left(\frac{\partial \varphi}{\partial t}\right)+d x\left(\frac{\partial \varphi}{\partial t}\right) \& d \gamma=d t\left(\frac{\partial \gamma}{\partial t}\right)+d x\left(\frac{\partial \gamma}{\partial x}\right)$. 52 Acreditamos que o correto seria $\mathrm{P}^{\prime} \mathrm{M}^{\prime}$. 
o espaço $\mathrm{PMP}^{\prime} \mathrm{M}^{\prime}$ é $=y y \varphi \gamma d t$. Ora, a densidade em $\mathrm{PM}$ sendo $=\varphi+d t\left(\frac{d \varphi}{d t}\right)$, a quantidade de éter que ocupa o tubo ABPM será $=\int \varphi y y d x+d t \int y y d x\left(\frac{d \varphi}{d t}\right)$ : adicionemos aí a pequena porção $\mathrm{PMP}^{\prime} \mathrm{M}^{\prime}=y y \varphi \gamma d t$, e retiremos daí a pequena porção $\mathrm{ABA}^{\prime} \mathrm{B}^{\prime}=f f \pi \omega d t$; é necessário que o resto seja igual à porção que ocupava antes o tubo ABPM, que é $=\int \varphi y y d x$. Donde tiramos esta igualdade:

$$
d t \int y y d x\left(\frac{d \varphi}{d t}\right)+y y \varphi \gamma d t-f f \pi \omega d t=0,
$$

[p. 138]

a qual sendo dividida por $d t$ dá:

$$
f f \pi \omega-y y \varphi \gamma=\int y y d x\left(\frac{d \varphi}{d t}\right) ;
$$

onde a integral $=\int y y d x\left(\frac{d \varphi}{d t}\right)$ deve ser tomada de modo que se considere o tempo $t$ como constante 5

XXIII. Em seguida, a massa de éter $\mathrm{PM} p m=\varphi y y d x$ sendo prensada pela face $\mathrm{PM}=y y$, pela elasticidade do éter sucedente, que ali é $=n \varphi$, e pela face $p m$, pela elasticidade do éter precedente 54 que é $=n \varphi$ $+n d x\left(\frac{d \varphi}{d x}\right)$, donde a força motriz para acelerar o movimento será $=-n y y d x\left(\frac{d \varphi}{d x}\right)$ que, dividido pela massa $\varphi y y d x$ dá a força aceleradora $56=-\frac{n}{\varphi}\left(\frac{d \varphi}{d x}\right)$. Ora, a massa $\mathrm{PM} p m$, tendo a velocidade $=\gamma$, é transportada durante o tempo $d t$ pelo espaço $\mathrm{PP}^{\prime}=\gamma d t$; sua velocidade será então $=\gamma+d t\left(\frac{d \gamma}{d t}\right)+\gamma d t\left(\frac{d \gamma}{d x}\right)$, e assim o aumento da velocidade $=d t\left(\frac{d \gamma}{d t}\right)+\gamma d t\left(\frac{d \gamma}{d x}\right)$, que deve ser igual ao produto da força aceleradora $-\frac{n}{\varphi}\left(\frac{d \varphi}{d x}\right)$ pelo tempo $d t$, donde tiramos:

$$
\left(\frac{d \gamma}{d t}\right)+\gamma\left(\frac{d \gamma}{d x}\right)=-\frac{n}{\varphi}\left(\frac{d \varphi}{d x}\right)
$$

que, junto com aquela que encontramos antes:

$$
f f \pi \omega-y y \varphi \gamma=\int y y d x\left(\frac{d \varphi}{d t}\right)
$$

\footnotetext{
53 O autor está pressupondo que a largura do tubo não varia no infinitésimo $d x$. Além disso, a integração diz respeito ao volume do trecho do tubo no tempo, fixado, de valor $t+d t$, por isso a integração é apenas na variável espacial, $x$.

54 "Sucedente" está à esquerda da figura I, em PM. E "precedente" está à direita, em pm, já que o sentido do fluxo de éter parece ser da direita para a esquerda.

55 Para calcular a força motriz, Johann Euler calcula a diferença de elasticidade em PM pm e multiplica pela área da secção transversal que, na sua notação, é yy.

56 No original: force accélératrice. A dimensão dessa grandeza depende da dimensão da constante $n$. Com efeito, a dimensão dessa força, que atua como uma aceleração em termos atuais, é $[n] /[$ metro $]$. Como vimos na seção 6 deste artigo, a elasticidade está próxima do nosso conceito de pressão. Se aceitarmos isso, como a dimensão de pressão é Newton por distância ao quadrado, a dimensão dessa grandeza é $[$ metro $] /[\text { segundo }]^{2}-$ uma aceleração.
}

contêm todas as condições pelas quais o movimento do éter deve ser determinado.

[p. 139]

XXIV. Mas as fronteiras da Análise nos param aqui prontamente, e não poderíamos resolver, de maneira generalizada, as duas equações que acabamos de encontrar. A desigualdade do movimento desde o primeiro começo parece opor os maiores obstáculos, porque assim que supomos que o movimento tenha chegado a uma espécie de uniformidade, de sorte que nem a densidade nem a velocidade variem mais no mesmo lugar, todas as dificuldades se esvanecem 57 Nessa hipótese, os termos $\left(\frac{d \varphi}{d t}\right)$ e $\left(\frac{d \gamma}{d t}\right)$, uma vez que $\varphi$ e $\gamma$ não dependem mais do tempo, se anulam, e nossas duas equações se tornam:

$$
\text { I. } f f \pi \omega-y y \varphi \gamma=0, \& I I . \gamma d \gamma=-\frac{n d \varphi}{\varphi},
$$

com a última sendo devidament 58 integrada resulta em 59

$$
n l \frac{\varphi}{\pi}=\frac{1}{2} \omega \omega-\frac{1}{2} \gamma \gamma, \& \varphi=\pi e^{\frac{\omega \omega-\gamma \gamma}{2 n}}
$$

que juntada à primeira 60 servirá para determinar $\varphi$ e $\gamma$. Ora, já que $n$ é um número extremamente grande 61 teremos aproximadamente $e^{62} \varphi=\pi\left(1+\frac{\omega \omega-\gamma \gamma}{2 n}\right)$, donde tiramos por aproximaçã ${ }^{63} \varphi=\pi\left(1-\frac{\omega \omega}{2 n y^{4}}\left(f^{4}-y^{4}\right)\right)$. Daí sabemos que, se $y>f$, a elasticidade em PM é maior do que em AB. Ora, se $y<f$, acontecerá o contrário.

XXV. Mas a equação $\varphi=\pi e^{\frac{\omega \omega-\gamma \gamma}{2 n}}$ nos faz saber que, lá onde a velocidade do éter é maior, sua elasticidade

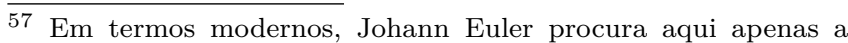
solução estacionária no tempo do sistema de equações, desconsiderando termos e soluções transitórios [2 p. 395].

58 Os limites de integração são os valores da velocidade e da densidade em AB e em PM; ou seja, a integral em $d \gamma$ vai de $\omega$ até $\gamma$, e a outra vai de $\pi$ até $\varphi$.

59 O "l" na equação era uma notação comum à época para logaritmos, incluindo o logaritmo natural [50, p. 105-107], como é o caso aqui. Em notação moderna a equação se torna: $n \ln \left(\frac{\varphi}{\pi}\right)=$ $\frac{1}{2} \omega^{2}-\frac{1}{2} \gamma^{2}, \& \varphi=\pi e^{\frac{\omega^{2}-\gamma^{2}}{2 n}}$.

60 A equação enumerada por Johann Euler como I.

61 Afirmado por Johann Euler no parágrafo V.

62 Johann Euler parece ter usado a técnica de expansão em polinômios de Taylor. Essa técnica já existia, Brook Taylor havia publicado seu trabalho sobre cálculo em 1715. Colin Maclaurin (1698-1746) chegou a um resultado similar um pouco depois, em 1742 32 p. 613-616].

63 A aproximação feita aqui foi a igualar $\pi$ e $\varphi$. Logo, a Equação I se torna $f f \omega=y y \gamma$. É notório a semelhança com a dinâmica de fluidos incompressíveis. Em fluidos compressíveis temos $f f \pi \omega=y y \varphi \gamma$, mantendo a notação do texto original. Isto é, a área de uma secção transversal de um tubo, multiplicada pela densidade e a velocidade do fluido nela, se manterá constante ao longo do tubo. Em fluidos incompressíveis, as densidades, sendo nomeadas de $\pi$ e $\varphi$, não variam ao longo do tubo e podem ser canceladas, resultando na expressão $f f \omega=y y \gamma$. Johann Euler a utiliza, elevando-a ao quadrado e aplicando-a na expressão $\varphi=\pi\left(1+\frac{\omega \omega-\gamma \gamma}{2 n}\right)$. Disso resulta a expressão do texto. O cálculo sem a aproximação é apresentado neste artigo, na seção 4 . 
deve ser menor, e reciprocamente, onde o éter se move menos rapidamente, ou até mesmo em repouso, lá sua elasticidade será maior. Ora, ainda que essa equação só aconteça quando o movimento do éter se tornou permanente, o que nunca acontece, as

[p. 140]

conclusões que acabo de tirar acontecerão também quando o movimento já se aproxima de um estado de permanência, e poderemos até vê-las como gerais e aplicar desde os primeiros instantes do movimento, contanto que nos contenhamos com os enunciados gerais, sem determinar a proporção das elasticidades em relação às velocidades diferentes. Também é fácil de se convencer dessas conclusões grosso modo, pois, já que a elasticidade do éter faz esforço para pôr o corpo em movimento, assim que ela consegue produzir seu efeito, já que uma parte dos esforços é aí empregada, é necessário que a elasticidade seja aí diminuída, de modo que quanto maior for a velocidade, tanto menor deve ser a elasticidade.

XXVI. Após essa observação geral, que será de grande importância nas pesquisas seguintes, retornemos ao nosso corpo eletrizado colocado no ar. Como neste corpo o éter está mais ou menos elástico do que no ar, à medida que o equilíbrio se restabelece pouco a pouco, a eletricidade diminuirá. Quanto mais prontamente isso acontecer, mais o éter será liberado tanto no corpo quanto no ar. Logo, o ar continuando o mesmo, os corpos cujos poros são mais abertos perderão sua eletricidade mais rapidamente, e nessa classe deve-se incluir a água, os metais, os corpos dos animais etc. Mas os outros corpos, cujos poros são muito estreitos e dificilmente deixam o éter escapar, conservarão sua eletricidade por um tempo maior. Para o ar, cuja constituição está sujeita a grandes mudanças, o mesmo corpo conserva por mais tempo sua eletricidade quando o ar está bem seco, o que nos faz ver que, nesse estado, o ar tem seus poros bem estreitos, mas quando o ar está úmido e participa da natureza da água, as partes aquosas, com as quais ele está misturado, deixando seu éter escapar facilmente, a eletricidade dos corpos deve aí se perder mais rapidamente. Julgar-se-á também facilmente que o tamanho do corpo deve contribuir muito para isso: um corpo pequeno será despojado mais rapidamente de sua eletricidade do que um grande, onde há mais éter a ser reduzido até o equilíbrio.

[p. 141]

XXVII. Mas a forma dos corpos entra principalmente em consideração aqui. Porque, já que o éter sai ou entra pelos poros que se encontram na superfície do corpo: onde há mais superfície em proporção à mesma quantidade de massa, aí também a comunicação do éter será maior. Isso acontece nos ângulos e principalmente nas pontas ${ }^{64}$ e é também nesses pontos que se observa que os efeitos da eletricidade são mais sensíveis. Porque

\footnotetext{
64 Johann Euler se refere aqui ao que conhecemos como poder das pontas. Esse fenômeno já era conhecido e foi analisado por, dentre outras pessoas, Benjamin Franklin.
}

não apenas há um maior número de poros que levam a uma ponta do que haveria se a ponta estivesse cortada, mas esses poros se comunicam também com vários outros que estão no interior dos corpos, de modo que nesses pontos o éter deve ou sair ou entrar em maior abundância, conforme a eletricidade do corpo seja positiva ou negativa. Logo, se o corpo tem vários ângulos ou pontas, ele perderá muito mais rapidamente sua eletricidade do que se não tivesse; donde se pode concluir que um corpo esférico, cuja superfície é bem polida, é o mais propício para conservar por mais tempo sua eletricidade.

XXVIII. Quando a eletricidade do corpo é tão grande que o movimento do éter, para sair ou entrar pelos poros da superfície se torna muito impetuoso, o que deve acontecer principalmente nos ângulos e nas pontas, o éter será posto num movimento de vibração capaz de produzir faíscas e brilhos luminosos, assim como o ar, quando fortemente agitado, causa um barulho. É também nesses pontos que se observa, sobretudo na escuridão, uma luz que é tanto mais viva quanto eletrizado for o corpo, e quanto mais ele tem seus poros abertos. Eis aqui então a explicação do principal fenômeno que esse caso nos oferece, pois eu não quero relatar aqui os fenômenos que se observam quando se aproxima um outro corpo desse corpo eletrizado, já que eu considero aqui somente um único corpo situado no ar sem que outro corpo possa ter a mínima influência sobre ele. É também a razão pela qual não vou falar sobre a sensação que percebemos quando aproximamos a mão ou o rosto de tal corpo eletrizado.

[p. 142]

XXIX. Tendo desenvolvido os casos de um único corpo eletrizado, passo a considerar dois corpos que estejam tão próximos um do outro que o efeito da eletricidade causado por um se estenda até o outro, porque se seu distanciamento fosse maior, aconteceria com cada um como se o outro não existisse. Aqui temos vários casos a examinar: se apenas um dos corpos, ou ambos, são considerados eletrizados, e esse último caso se divide ainda em dois, de acordo com se a eletricidade desses dois corpos é de mesma natureza, ou que uma seja positiva e outra negativa. Além disso, tanto a natureza de cada corpo, enquanto concede uma passagem mais ou menos livre ao éter, quanto o grau de eletricidade, podem variar infinitamente os fenômenos. Concebo esses dois corpos situados no ar, ou em outro meio qualquer, onde o éter se encontra em seu estado natural, em relação ao qual o éter contido em um, ou em ambos os corpos, seja mais ou menos elástico.

XXX.

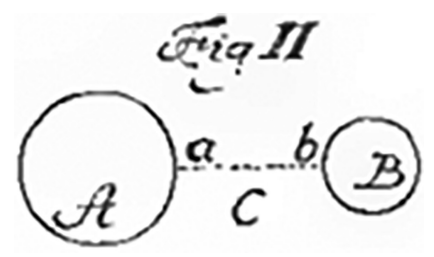

Revista Brasileira de Ensino de Física, vol. 43, e20200396, 2021 
Seja inicialmente apenas o corpo A eletrizado, e que a elasticidade do éter seja maior do que no ar, ou ainda que sua eletricidade seja positiva, e no outro corpo B suponho a elasticidade [de seu éter] igual à [elasticidade do éter] do ar ${ }^{65}$ Primeiramente o éter escapará do corpo A e se insinuará no ar em volta, que, adquirindo mais éter se tornará eletrizado, caso esse aumento não seja logo dissipado pelo ar mais afastado. Entretanto, o ar que circunda o corpo A, recebendo incessantemente as emanações do éter, conterá mais éter do que exige seu estado natural, e formará com isso em volta do corpo A uma espécie de atmosfera elétrica. Agora, se o corpo B recebesse o éter tão dificilmente quanto o ar, ele não mudaria nada no estado do corpo A; mas tirando da atmosfera um pouco de éter, ele se tornará, ainda que pouco, positivamente eletrizado. Ora, se o corpo B tem seus poros mais abertos para receber facilmente o éter que flui do corpo A para ele pelo espaço $\mathrm{C}$, o movimento do éter, encontrando menos obstáculos para se espalhar por esse espaço C, será ali acelerado, e assim sua elasticidade diminuirá, como foi provado acima. 66 [p. 143]

XXXI. Então, o corpo A sendo mais pressionado pelo éter por todos os lados do que na direção C, ele será empurrado em direção ao corpo $\mathrm{B}$ e reciprocamente o corpo B, em torno do qual o éter está em repouso, excetuando o espaço $\mathrm{C}$, será também menos pressionado nesse ponto e, partindo disso, empurrado na direção do corpo A de forma que esses dois corpos parecerão se atrair mutuamente. Essa atração será tanto maior quanto mais poros abertos o corpo B tiver, já que essa circunstância serve para aumentar o movimento dentro do espaço C. Mas então o próprio corpo B se tornando pouco a pouco eletrizado, e também positivamente eletrizado, os fenômenos que resultarão depois não pertencem mais ao caso que aqui examino. De resto, vê-se que quanto mais próximos os dois corpos A e B estão, maior se tornará a agitação do éter no intervalo C. Quando ela aumenta ao ponto de excitar um movimento de vibração, ver-se-á uma luz entre os dois corpos e, já que o ar participa ao mesmo tempo dessa agitação, essa luz será acompanhada de um assobio; a comunicação do éter se fazendo então muito prontamente, o equilíbrio será logo restabelecido e, com isso, a eletricidade será extinta.

XXXII. Esses mesmos fenômenos devem ainda acontecer quando o corpo A é considerado eletrizado negativamente, enquanto o corpo B continua não eletrizado. Então o éter espalhado no ar, tendo uma maior elasticidade, se insinuará para dentro dos poros do corpo A e o movimento pelo qual ele é levado para dentro formará em torno desse corpo uma atmosfera negativamente elétrica.

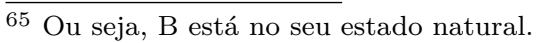

66 O autor não é claro nesse ponto, mas subentende-se que o éter encontra menos obstáculos em $\mathrm{C}$ porque, sendo $\mathrm{C}$ o menor caminho, também terá a menor quantidade de poros obstrutivos para o movimento do éter. Caminhos maiores entre os corpos A e B terão mais poros obstruídos.
Por causa desse movimento, a elasticidade do éter em $\mathrm{C}$ será menor do que do lado oposto do corpo B, o qual será consequentemente empurrado em direção ao corpo A. Ora, o corpo B também fornecerá seu éter que passará para dentro do corpo A de forma que à medida que a eletricidade do corpo A diminui, o corpo B, despojado de seu éter, se torna cada vez mais eletrizado. Nos primeiros instantes que isso ocorre, a grande rapidez do éter no espaço C fará diminuir sua elasticidade nesse espaço e, com isso, os dois corpos serão empurrados um em direção ao outro. Numa proximidade muito grande, a rapidez do éter relampejará em luz e

[p. 144]

produzirá os mesmos fenômenos que no caso precedente; nesse caso também toda a eletricidade será logo extinta.

XXXIII. Vejamos agora o que deve acontecer quando o corpo B é também eletrizado da mesma espécie que o corpo A, já que o caso precedente logo se reduz a este aqui. Seja de início a elasticidade do éter dentro desses dois corpos maior que a no ar que os circunda; ou seja, suas eletricidades são positivas. Está claro que se a eletricidade de um é muito fraca em relação à do outro, os mesmos fenômenos serão produzidos aproximadamente como no caso precedente, sendo que o éter, escapando do mais forte, se insinua para dentro do mais fraco e aumenta sua eletrização. Mas, se a eletricidade do corpo B é aproximadamente tão forte quanto a do corpo A, os fenômenos devem ocorrer bem diferentemente; pois, já que o éter escapa pelos pontos $a$ e $b$ com forças quase iguais e opostas, seu movimento será, por isso, retardado. Então, o movimento será menor em $\mathrm{C}$ que nos outros pontos ao redor dos corpos e, com isso, sua pressão ou elasticidade se tornará mais forte. Logo, esses dois corpos estando mais pressionados em $a$ e $b$ que alhures serão repelidos um do outro. Também os aproximando, nenhuma faísca será excitada entre eles, já que um impede a saída do éter do outro e se as bordas desses corpos são luminosas em outros pontos por causa do éter que dali escapa, essa luz parecerá, antes, apagada nos pontos $a$ e $b$.

XXXIV. A mesma coisa deve acontecer quando a elasticidade do éter for menor dentro de ambos os corpos do que no ar; ou seja, suas eletricidades são negativas e mais ou menos igualmente fortes. Porque o éter entre esses dois corpos em $\mathrm{C}$ sendo levado na direção de um e do outro, seu movimento não será tão rápido no intervalo $\mathrm{C}$ que nos outros pontos em torno dos corpos e, com isso, sua elasticidade sendo aí maior, os dois corpos serão repelidos um do outro, tudo como antes e, pelo mesmo motivo, não haverá luz alguma quando da aproximação desses dois corpos. Agora podemos dizer o que deve acontecer quando aproximamos um corpo não-elétrico ${ }^{67} \mathrm{~B}$ de um corpo eletrizado A. De início o

67 No original: non électrique. Aqui, por força do contexto, a tradução só fazia sentido com "não-elétrico", ao invés de "não eletrizado". Um não-elétrico é um corpo que não eletrizável por atrito. Grosseiramente, é o que entendemos hoje como metais. 
corpo B será atraído e ao mesmo tempo se tornará mais e mais eletrizado,

[p. 145]

enquanto que o corpo A perde de sua eletricidade. Mas, assim que a eletricidade do corpo B atingir um certo grau, os dois corpos começarão a se repelir mutuamente e a eletricidade do corpo B não será mais aumentada.

XXXV. O último caso é quando os dois corpos estão eletrizados, mas um positiva e o outro negativamente. Seja então a elasticidade do éter em A maior e em B menor que no ar, de forma que a eletricidade no corpo A seja positiva e em $B$, negativa. Já que o éter escapa de todas as partes do corpo A e entra no corpo B, aquele que escapa por $a$ sendo levado por si mesmo a $b$, o movimento dentro do intervalo $\mathrm{C}$ será muito mais rápido que fora dele e, com isso, sua elasticidade será menor. Por essa razão os dois corpos se atrairão mais fortemente que se um deles não estivesse eletrizado e aproximando-os bastante, a faísca aí excitada, será muito mais viva, já que a agitação do éter em $\mathrm{C}$ é aumentada pela qualidade de ambos os corpos. Mas essa mesma circunstância será a causa pela qual ambos os corpos perderão suas eletricidades mais prontamente, porque o corpo B acelera a saída do éter do corpo A e este acelera a entrada do éter para dentro do corpo B.

XXXVI. Até aqui eu supus os corpos tão pequenos, ou antes de uma natureza tal, que por toda a sua extensão o éter se encontra no mesmo grau de elasticidade, de sorte que o corpo inteiro seja, ou não eletrizado, ou em todas as suas partes igualmente eletrizado. Mas a experiência nos faz ver que pode haver corpos cuja eletricidade em uma parte é positiva e em outra, negativa. Pode acontecer, então, que em diversas partes do mesmo corpo a elasticidade do éter seja assaz diferente, sem que ela retorne tão rapidamente ao equilíbrio, o que está bem de acordo com o que eu disse no começo sobre a dificuldade que o éter encontra para passar pelos poros dos corpos e que, talvez, não haja nenhum que permita ao éter uma passagem totalmente livre. Então, por mais diferente que seja a elasticidade do éter em diferentes partes do mesmo corpo, essa diversidade pode subsistir por bastante tempo,

[p. 146]

principalmente quando o éter não é agitado, já que só o excedente da elasticidade em um lugar [do corpo] não é suficiente para vencer as dificuldades que a pequenez dos poros lhe opõe. A pedra de Ceilão chamada turmalina 68 nos oferece aqui um exemplo bastante notável de um corpo que é suscetível às duas espécies de eletricidade ao mesmo tempo 69

\footnotetext{
68 Uma pedra comum na fabricação de joias no começo do século XVIII. Foi nomeada logo de início como Aschentrekker e Aschenzieher, pela sua propriedade de atrair cinzas quando aquecida sobre carvão em brasa. O nome turmalina, derivado do cingalês tóramalli, tornou-se padrão depois dos trabalhos de Franz Aepinus (1724-1802) [51, p. 23-24].

69 Se uma pedra de turmalina for imersa em água quente, ela fica eletrizada positivamente em uma face, e negativamente na face
}

XXXVII. Mas o caso é bem diferente quando o éter não está em repouso, mas se encontra num movimento muito rápido porque, então, ele ultrapassa facilmente as dificuldades relatadas, comunicando seu movimento quase instantaneamente a distâncias mais longínquas. Os corpos metálicos são os mais propícios a esse fim, e observa-se que a eletricidade é transmitida por um fio de latão, qualquer que seja o seu comprimento, com uma velocidade prodigiosa, quando aproximando-se um corpo eletrizado, o éter seja obrigado a entrar ou sair dele. Essa velocidade deve ser suficiente para que o éter posto em movimento ultrapasse facilmente os obstáculos nos quais ele pararia quase inteiramente se estivesse em repouso. Então, por mais dificuldades que o éter tranquild ${ }^{70}$ possa encontrar para atravessar os poros dos corpos, ainda que sua elasticidade difira muito da de seu vizinho, assim que submetido a um movimento rápido, ele é capaz de se comunicar instantaneamente a grandes distâncias. Ora, nós acabamos de ver que ao aproximar um corpo eletrizado de outro, que não está eletrizado, ou que o está em sentido contrário, o movimento do éter deve ser bem impetuoso.

\section{XXXVIII.}

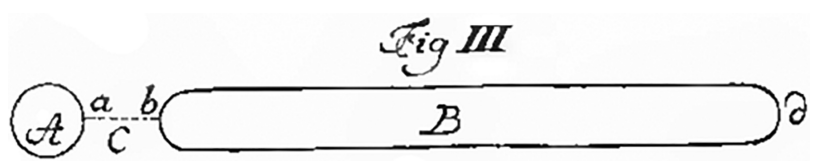

Assim, se o corpo B tem uma forma alongada $b d$ e que seus poros sejam mais abertos, o que acontece quando se pega uma barra metálica, então aproximando um corpo eletrizado A, cuja eletricidade seja positiva, de uma ponta $b$ dessa barra, que eu suponho não-eletrizada, o éter que entra em $b$ será transmitido dentro dessa barra muito rapidamente até a outra ponta $d$, onde seu movimento, devido à dificuldade de sair pelo ar, será subitamente bloqueado. A rapidez desse movimento levará mais éter de $b$ em direção a $d$ que se esse movimento fosse menos rápido, de forma que o éter em $d$ será mais

[p. 147]

comprimido que em $b$ e, com isso, sua elasticidade será maior. Então, se retirarmos subitamente o corpo eletrizado A, notaremos em a uma eletricidade positiva mais forte que em $b$, e poderá mesmo acontecer que a eletricidade em $b$ seja negativa, já que a rapidez do movimento retirou mais éter de $b$ do que o necessário para leva-lo ao estado natural. E dado que, a partir da suspensão do movimento, a comunicação do éter

oposta. Louis Lémery (1678-1721) descreveu suas propriedades elétricas em 1717, mas ela só foi mais bem estudada após os trabalhos de Franz Aepinus, em 1757. Depois de Aepinus, a turmalina tornou-se assunto em alguns trabalhos de John Canton, Benjamin Wilson, René-Just Haüy (1743-1822), e outros. Para mais sobre as propriedades da turmalina e a história das pesquisas elétricas a respeito dela, ver: [51].

70 Isto é, em baixa velocidade. 
dentro da barra encontra mais obstáculos, esse estado de desigualdade poderá subsistir por algum tempo, de forma que a ponta $d$ seja dotada de uma eletricidade positiva enquanto que a da outra ponta $b$ é negativa. $\mathrm{O}$ contrário acontecerá se a eletricidade de A for negativa.

XXXIX. Daí compreendemos facilmente como é possível excitar dentro do mesmo corpo as duas espécies de eletricidade ao mesmo tempo. Para isso é necessário que o corpo B tenha uma forma alongada e que o éter ali possa receber um movimento muito rápido. Se esse corpo fosse de um material onde a passagem do éter encontrasse mais obstáculos, uma tal desigualdade de eletricidade se conservaria mais facilmente, mas também seria mais difícil colocá-lo em tal estado, já que um movimento tão rápido, exigido por esse fenômeno, não poderia acontecer. Notamos acima que aproximando um corpo eletrizado de um não eletrizado, este último adquire uma eletricidade da mesma espécie. Mas agora vemos que nos enganaríamos muito se quiséssemos formular uma regra geral, já que pode acontecer de um corpo A eletrizado positivamente comunicar ao outro em $b$ uma eletricidade negativa. Ora, como nesse caso a eletricidade na ponta oposta $d$ é positiva e, portanto, mais forte, poderemos admitir a regra supracitada como geral, conquanto se adicione a condição segundo a qual não se deve considerar a eletricidade do corpo $\mathrm{B}$ pela ponta $b$ pela qual havíamos aproximado o corpo eletrizado, mas antes pela ponta oposta $d{ }^{71}$

XL. Assim, para considerar qual espécie de eletricidade será comunicada a um pequeno corpo mergulhado na atmosfera de um corpo eletrizado positivo ou negativo, é certo, primeiro, que ela seria sempre a

[p. 148]

mesma que a do corpo eletrizado, se o pequeno corpo estivesse suspenso no ar por si mesmo. Mas, já que esse pequeno corpo deve estar apoiado ou suspenso por um outro corpo fixo, deve-se também levar este último em consideração, e a maneira com a qual ele está ali concatenado: se é por meio de um fio de seda ou de um material tal que tenha seus poros bem cerrados, pelos quais o éter é dificilmente transmitido; de mesma forma que se o pequeno corpo flutuasse livremente dentro da atmosfera do corpo elétrico e adquirindo, por conseguinte, a mesma espécie de eletricidade. Mas, se esse corpo pequeno se liga a um fio de latão, ou a um material pelos poros do qual o éter encontra uma passagem muito mais livre, e que esse fio esteja concatenado a um corpo de propriedade semelhante, poderá acontecer que a rapidez do movimento do éter torne-se tão grande que o pequeno corpo adquira uma eletricidade contrária à do corpo em cuja atmosfera ele está mergulhado, uma vez que o efeito da eletricidade é tirado do pequeno corpo pela rapidez do movimento dentro do corpo ao qual ele está concatenado.

\footnotetext{
71 Johann Euler não deixa claro o porquê da ponta $d$ ser mais apropriada para decidir qual a eletricidade do corpo B da figura III.
}

XLI. Então, para explicar os fenômenos da eletricidade, é de suma importância conhecer bem a natureza dos corpos em relação à passagem mais ou menos livre que o éter encontra ao atravessá-los. Ainda que haja em relação a isso uma infinidade de graus diferentes, bastará observar três espécies principais e referenciar todos os corpos a elas. A primeira espécie conterá os corpos que mantêm seu éter bem cerrado, de forma que ele só poderá entrar e sair com muita dificuldade, e que encontra ao atravessá-los uma passagem bastante emaranhada. A segunda espécie contém os corpos cujos poros não são nem muito cerrados nem muito abertos, e que ocupam um meio entre a primeira espécie e a terceira. Ora, referencio à terceira espécie os corpos que têm seus poros mais abertos através dos quais o éter encontra uma passagem assaz livre, ainda que lhe falte muito para que ele seja totalmente livre. Vê-se bem que não se poderiam fixar os limites entre essas espécies e que encontraremos muitos corpos próximos à média que nos deixarão em dúvida se devem ser aí referenciados [p. 149]

ou antes a um dos extremos. Mas essa incerteza não deve causar embaraço. ${ }^{72}$

XLII ${ }^{73}$ Entre os corpos da primeira espécie contamse o vidro, diamante, enxofre, cera da Espanha ${ }^{74}$ breu, seda e outros semelhantes para os quais a principal referência é o ar quando este está puro. As experiências feitas sobre eletricidade fazem-nos ver que essa virtude quase não se comunica a esses corpos quando aproximamos deles corpos eletrizados, donde sabemos que os poros desses corpos devem ser muito estreitos e que o éter encontra ali obstáculos quase invencíveis, tanto para se liberar quanto para se inserir. Poderia acontecer que os poros fossem assaz largos, mas eles quase não tivessem comunicação entre si, o que produziria o mesmo efeito que se os poros fossem extremamente estreitos. Talvez a falta de comunicação entre os poros constitua antes um caráter desses corpos do que a própria pequenez dos poros, o que significa a mesma coisa. Ora, se os poros comunicam-se assaz livremente entre si, isso será o caráter da terceira espécie, que contém os metais, os corpos dos animais, a água e talvez todos os outros líquidos. Os outros corpos, como madeira, argilas, papel etc. que parecem ocupar um meio entre a primeira e a terceira espécie, preencherão a segunda classe.

XLIII. Nomeamos ordinariamente os corpos da primeira espécie elétricos per se, já que podemos excitar a eletricidade neles sem o recurso de um outro corpo que esteja já eletrizado; e, pela mesma razão, nomeamos os

\footnotetext{
72 Grosso modo, os corpos da primeira espécie eram os elétricos per se da época e, atualmente, nós os conhecemos como bons isolantes. Os corpos da terceira espécie eram os não-elétricos (ou não-elétricos per se). São os nossos bons condutores, como muitos metais. Os corpos da segunda espécie são intermediários entre os dois.

${ }^{73}$ Neste parágrafo, Johann Euler discute a comunicação elétrica; isto é, a condução.

74 É um tipo de cera usada como lacre.
} 
corpos da terceira espécie não-elétricos per se, já que a eletricidade não poderia ser aí excitada sem o recurso de um corpo elétrico. Mas, para evitar toda confusão que seria a temer dessas denominações, sou obrigado a abandoná-las inteiramente, fixando-me nas definições principais, conforme as quais nomearei sempre um corpo [como] eletrizado quando o éter encerrado dentro do seus poros não está em equilíbrio com o éter dos corpos vizinhos; e um corpo não-eletrizado será sempre aquele no qual

[p. 150]

o éter se encontra no mesmo grau de elasticidade que dentro dos corpos que o avizinham. Eu não gostaria então de nomear um corpo elétrico per se quando ele não está eletrizado, nem um corpo não-elétrico per se quando ele está de fato eletrizado. A adição das palavras per se não parece suficiente para nos garantir contra toda ambiguidade. Aliás, as espécies [de corpos] estabelecidas são mais apropriadas para marcar essa distinção, sem deixar o menor equívoco.

XLIV. Entretanto, é muito notável que os corpos da primeira espécie, que são os menos suscetíveis à eletricidade, sejam ao mesmo tempo os mais propícios a imediatamente excitar neles mesmos essa virtude quando não há ainda outros corpos eletrizados. Essa circunstância é bem diferente da que considerei até aqui, onde supus que já haja corpos eletrizados, sem me embaraçar com a causa pela qual eles assim se tornaram. E, tomando um tal corpo, muito certamente ele quase não comunica sua virtude aos corpos da primeira espécie, enquanto que ela [a virtude] se comunica muito comodamente aos corpos da terceira espécie. Mas, quando se trata de excitar dentro de um corpo a eletricidade sem o recurso a um outro corpo eletrizado, acontece precisamente o contrário, e vê-se que os corpos da primeira espécie são neste caso mais propícios 75 Outros [acadêmicos] começaram suas pesquisas por este [último] caso, o que parece mais natural, já que é necessário ter corpos eletrizados antes que se possa fazer experiências sobre a eletricidade. Mas, tendo aqui um objetivo diferente, saber explicar os fenômenos da eletricidade, esse mesmo objetivo me obrigou a inverter a ordem natural.

XLV. A fricção é o meio ordinário de excitar a eletricidade, ou de tornar os corpos eletrizados. Ora, esse meio não se estende a todos os corpos, deve-se excluir os da terceira espécie que, aliás, são os mais propícios a se tornarem eletrizados por comunicação. Isso não deve parecer estranho porque qualquer alteração que a fricção possa produzir no equilíbrio do éter, que está

\footnotetext{
75 Aqui, o autor discute a eletrização por atrito. Ele afirma, grosso modo, que os isolantes se eletrizam melhor por atrito, e não por condução. Os metais (corpos da terceira espécie) eram os que não se eletrizavam por atrito, mas que comunicavam sua eletricidade para todas as partes de seu corpo com facilidade (quando eletrizados), algo que já havia sido mostrado por Stephen Gray 1 p. 239-264]. Apenas em 1778 Joseph von Herbert (17251794) conseguiu eletrizar os metais por atrito [17 p. 15-16].
}

encerrado dentro dos corpos friccionados, ela deve ser imediatamente restabelecida

[p. 151]

quando os poros dos corpos são bem abertos. Concebamos que se friccionem dois corpos da terceira espécie um contra o outro, e que por essa ação o equilíbrio do éter seja agora perturbado, tornandose sua elasticidade maior em um e menor no outro, essa desigualdade não poderia durar e o equilíbrio será restabelecido antes que se possa perceber um fenômeno da eletricidade ${ }^{76}$ A livre passagem que o éter encontra para passar de um para o outro não permitirá nem mesmo que nasça a menor desigualdade dentro da elasticidade do éter. Ora, se um dos corpos friccionados, ou ambos, são da primeira espécie, ou tais que o éter só poderia passar muito dificilmente de um para o outro, compreendemos pela mesma razão que a fricção perturba o equilíbrio do éter, essa alteração poderá subsistir de forma que os corpos se tornem efetivamente eletrizados.

XLVI. Quando se esfregam dois corpos um contra o outro, há somente dois casos que podem ocorrer porque, ou a elasticidade do éter encerrado dentro dos corpos se mantém a mesma, ou ela será alterada. No primeiro caso nenhuma eletricidade será excitada, mas no outro não deixará de fornecer [fenômenos elétricos]. Vejamos então o que deve ocorrer neste último caso. Se o atrito é a causa do aumento do grau de elasticidade [do éter] em um dos corpos atritados, é necessário que a quantidade de éter ali seja aumentada. Esse crescimento vem, ou do ar ao redor, ou do outro corpo, que deve perder precisamente o mesmo tanto. Ora, não parece que o éter venha do ar, já que no atrito os corpos se tocam diretamente, e que o pouco de ar que resta entre os corpos não poderia fornecer, além de que o ar retém muito fortemente o seu éter. É necessário então que ele venha do outro corpo e, por isso, este tornar-se-á eletrizado negativamente, enquanto que o outro recebe uma eletricidade positiva. $\mathrm{O}$ contrário acontecerá se supusermos que o atrito diminui [a quantidade de] éter no primeiro [corpo], tornando-o negativamente eletrizado, porque assim o outro corpo adquirirá uma eletricidade positiva.

[p. 152]

XLVII. Poderíamos objetar que seria possível que a elasticidade do éter dentro de um corpo se tornasse maior sem que sua quantidade fosse aumentada, e que talvez o atrito produzisse tal efeito, assim como nós sabemos que o calor aumenta a elasticidade do ar sem que ele se torne mais denso ${ }^{77}$ Mas, além dessa conjectura não ter nenhum fundamento, ela é destruída pelos próprios

\footnotetext{
76 Aqui, Johann Euler continua sua discussão sobre formas de eletrização, comparando a comunicação elétrica com o atrito. Neste parágrafo, ele também chama a atenção de que os metais (palavra nossa), apesar de não se eletrizarem por atrito, são mais propícios à conduzirem a eletricidade.

77 Essa afirmação sobre o ar é feita em um trabalho de 1753 de Leonhard Euler sobre o equilíbrio dos fluidos. Nele, Leonhard Euler afirma que em um fluido compressível, a elasticidade depende da
} 
fenômenos da eletricidade que provam constantemente que, quando pelo atrito de dois corpos, um se torna positivamente eletrizado, observa-se no outro sempre uma eletricidade negativa, e vice-versa, a menos que um tenha uma livre comunicação com corpos da terceira espécie, que restabeleçam prontamente o equilíbrio do éter. Também observamos que, quando se atritam dois corpos parecidos e do mesmo material um contra o outro, não se poderia excitar nenhuma eletricidade ${ }^{78}$ porque não haveria nenhuma razão pela qual a elasticidade do éter tivesse sido aumentada ou diminuída antes em um do que no outro. Se o atrito pudesse alterar a elasticidade do éter sem que, com isso, passasse alguma coisa de um corpo para o outro, a igualdade dos corpos [por si só] não destruiria esse efeito [de eletricidade sem movimentação do éter] 79

XLVIII. É certo então que o atrito só produz eletricidade enquanto uma quantidade de éter é transmitida de um corpo para o outro, e a elasticidade do éter dentro de um aumenta à medida que ela diminui no outro. Logo, para explicar esse efeito do atrito deve-se mostrar como é possível que, atritando dois corpos um contra o outro, uma parte do éter seja expulsa de um e obrigada a adentrar o outro. De fato, se considerarmos que os poros de um corpo podem ser comprimidos pelo atrito 80 o éter que está ali contido será expulso e obrigado a adentrar o outro, contanto que os poros deste não estejam igualmente, ou mais, comprimidos, caso em que a entrada não poderá ocorrer. Mas, se os poros desse corpo estão em estado de receber o éter que é expulso do outro, e que pela continuação do atrito essa transmissão seja mantida, a desigualdade da elasticidade do éter dentro desses

[p. 153]

dois corpos deve se tornar cada vez maior, até que a força do atrito não seja mais capaz de aumentá-la ainda mais. Ora, para esse efeito é necessário que os poros, que foram uma vez comprimidos, se restabeleçam a cada instante pela sua própria elasticidade ${ }^{81}$ para serem preenchidos

densidade (não necessariamente de forma linear). Se mantivermos o valor da densidade constante enquanto o do calor aumenta, a elasticidade aumenta 36, p. 224-225]. Como tanto no trabalho de Leonhard Euler quanto neste de Johann Euler, a elasticidade está bastante próxima do nosso conceito de pressão $P$ (seção 6 deste artigo), podemos comparar esse raciocínio com a atual lei de gases ideais, onde $P V=n R T$, considerando calor como equivalente à temperatura $T$. O número de mols, $n$, pode ser convertido à densidade do gás, $d$, usando a massa molar, $M$, constante. Nesse caso, $M P=d R T$. Se controlarmos a densidade de um gás em um recipiente rígido hermeticamente selado, o aumento da temperatura acarreta um aumento de pressão (elasticidade).

78 Idealmente, sim, mas defeitos, impurezas e microfissuras nos materiais são suficientes para que eles se eletrizem.

79 Dois objetos similares do mesmo material e mesma fabricação não deveriam se eletrizar, mas sempre há diferenças microscópicas (impurezas, ranhuras, etc.) que os eletrizariam em caso de atrito. 80 Johann Euler não explica porque um corpo atritado teria seus poros comprimidos; subentende-se que seja devido ao choque mecânico que ocorre quando se atrita objetos.

81 Aqui, Johann Euler se refere a elasticidade dos poros do corpo. Não confundir com a elasticidade do éter. de novo de éter, e que este seja ainda retirado pelo atrito. É somente por tal operação reiterada que o corpo pode ser esgotado de seu éter ao ponto de se tornar significativamente eletrizado.

XLIX. É então essencial à produção da eletricidade que os poros de um dos corpos atritados sejam comprimidos ao ponto de expulsar o éter aí encerrado, e que ao menos uma parte passe para dentro dos poros do outro corpo porque não há nenhuma dúvida que uma boa parte volte para os poros interiores do primeiro corpo. É por esse meio que se obtém o início de uma [sinalização de que há] eletricidade [em um corpo]. Mas, para levá-la a um mais alto grau é necessário que os poros comprimidos se restabeleçam antes de serem submetidos de novo ao atrito; nesse ínterim, onde esses poros do corpo atritante são liberados, o éter do interior ali entrará para preenchêlos à medida que eles [os poros] se restabelecem. Estando então esses poros de novo atritados e comprimidos, uma nova porção passará para o corpo atritante, e reiterando várias vezes a mesma operação, ambos os corpos se tornarão eletrizados, um positiva e o outro negativamente, contanto que nem um nem o outro sejam corpos da terceira classe que, por sua comunicação, destruiriam a eletricidade. Mas, se um só desses corpos está em comunicação com um corpo da terceira classe, uma vez que seu éter permanecerá quase em equilíbrio, e, por consequência, mais propício ou a receber o éter expulso do outro, ou a expulsar seu éter nele, a eletricidade deste se tornará mais significativa, o que está de acordo com as experiências.

L. A produção da eletricidade pelo atrito não poderia ocorrer a menos que os dois corpos que são atritados um contra

[p. 154]

o outro sejam de uma natureza totalmente diferente; de forma que, enquanto que os poros de um são assaz comprimidos para expulsar o éter, os do outro se mantêm assaz livres para receber uma parte do éter. Compreende-se também que ao menos um desses dois corpos deve ter seus poros fortemente estreitos, afim de que pelo toque do outro o equilíbrio do éter não seja logo restabelecido. Quer dizer que é necessário que um dos dois corpos seja da primeira espécie ${ }^{82}$ Se o outro o é também, ao menos na superfície que é atritada, haverá tanto menos a temer que pelo seu toque a eletricidade seja tão subitamente destruída. Mas, ainda que o interior do corpo tivesse seus poros muito abertos, isso não impediria a eletricidade do outro, ela seria antes avançada. Conforme a desigualdade da elasticidade do éter nos dois corpos atritados já se terá tornado grande, o aumento ulterior de eletricidade sucede tanto menos.

\footnotetext{
82 Grosso modo, Johann Euler estuda neste parágrafo a eletrização por atrito entre um isolante e um condutor. Aqui ele afirma que basta que um dos dois corpos atritados seja isolante.
} 
LI. ${ }^{83}$ Ora, não basta considerar a diversidade de matéria de que são compostos os dois corpos atritados, sua forma exterior pode também mudar bastante a produção da eletricidade, já que o atrito depende principalmente da superfície dos corpos. Observa-se também que dois tubos de vidro embora semelhantes, mas dos quais um tem sua superfície bem polida e o outro áspera podem produzir fenômenos totalmente contrários de eletricidade, ainda que sejam atritados pelo mesmo corpo, um se tornando eletrizado positiva e outro, negativamente. Isso acontece quando se atrita um e outro com um pedaço de pano de lã. É difícil decidir se os poros do vidro polido são mais comprimidos em se atritando com a lã, ou os do vidro não polido? Mas a decisão dessa questão nos levaria antes a julgar se a eletricidade que o Sr. Francklin nomeia positiva é efetivamente positiva ou negativa porque ele nomeia positiva a eletricidade que o tubo polido adquire, e negativa aquela do tubo áspero.

LII. Se a eletricidade do tubo polido atritado com um pano de lã fosse positiva, e a do tubo não polido, negativa, seguir-se-ia

[p. 155]

que seria mais fácil comprimir os poros do vidro não polido que da lã, e os da lã mais fácil do que os do vidro polido. Poderíamos talvez imaginar várias razões para provar que os poros do vidro não polido são mais compressíveis que os do vidro polido, pois parece que os primeiros dão mais aderência ao atrito que estes últimos. Mas, esse mesmo raciocínio fundado sobre uma suspeita que se pode ter a julgar pela estrutura aparente dos poros para conhecer a sua compressibilidade, esse mesmo raciocínio, como eu dizia, nos conduziria a inevitáveis contradições porque, como os poros da lã nos parecem ser mais compressíveis tanto do vidro polido, quanto do não polido, o vidro deveria sempre, qualquer que fosse sua superfície, dar uma eletricidade positiva. Daí vê-se facilmente que não se deve julgar a estrutura verdadeira dos poros pela sua forma aparente.

LIII. Todo esse raciocínio, então, ainda não derrubará minha Teoria porque, seja, como diz Sr. Francklin, a eletricidade do vidro polido positiva ou, como diz a minha Teoria, negativa, poderíamos num e no outro caso fazer tais objeções fundadas sobre a compressão que parece mais óbvia, se me for permitido dar a estes frágeis raciocínios o nome de objeções. É então necessário bem observar que não se trata aqui de compressão aparente, nesse caso a lã seria sem dúvida um corpo muito mais compressível que o vidro, fosse sua superfície polida ou áspera. Mas, trata-se antes da compressão a qual são suscetíveis os mínimos poros de um material que, sendo totalmente diferente da compressão grosseira, é muito possível que os poros da lã sejam menos compressíveis que os do vidro polido ou não polido. E, se acreditávamos

\footnotetext{
83 Neste parágrafo, entre outras coisas, o autor discute a dependência da eletrização com a da textura da superfície dos objetos.
}

ter encontrado razões pelas quais o vidro não polido deveria ser mais compressível que o polido, talvez essas razões não se reportem aos menores poros.

LIV. Entretanto, se pudéssemos determinar a qual espécie pertenceria uma única eletricidade natural, seria fácil determinar a espécie de todas as outras, já que as experiências mais fáceis

[p. 156]

decidem, de início, se a eletricidade de dois corpos elétricos é da mesma espécie ou não? Tendo assim encontrado que, quando se derrete enxofre e que se o deixa resfriar, ele adquire uma eletricidade oposta à de um vidro polido e excitado pelo atrito. Ora, o enxofre derretido não mostra nenhum traço de eletricidade ainda; ela só se manifesta após o resfriamento ${ }^{84}$ Ora, por isso o enxofre é reduzido a um menor espaço, o que indica um maior encolhimento dos poros contendo ainda a mesma quantidade de éter, já que pertence à primeira espécie ${ }^{85}$ É necessário que a compressão do éter e, por consequência, também a sua elasticidade, tenham se tornado maiores; sua eletricidade será, então, positiva e, por consequência, a do vidro polido, negativa. Se entrarmos em acordo sobre esse raciocínio, dever-se-á mudar os nomes dos quais Sr. Francklin se serve para distinguir as duas diferentes espécies da eletricidade, e os corpos que ele classifica como positivamente eletrizados, terão de fato uma eletricidade negativa, e vice-versa.

LV. As Experiências feitas sobre a eletricidade de uma bola de breu ou de lacre achatada por um golpe de martelo nos conduzirão às mesmas conclusões que o enxofre derretido. Porque nota-se que tendo suspendido ao redor de um globo de breu alguns pedaços de folha de ouro batido, e após ter achatado esse globo subitamente por um golpe de martelo, essas folhas de ouro batido, após serem atraídas, mostraram uma eletricidade resinosa, ou negativa segundo Sr. Francklin. Ora, aceitando que os poros do breu pelo achatamento súbito se retraem, é necessário que a compressão do éter dentro desses poros aumente, o que mostraria uma eletricidade positiva. E como essa eletricidade é contrária àquela do vidro polido,

\footnotetext{
84 O enxofre já havia sido usado por Stephen Gray, em 1732, em experimentos elétricos. Neles, Gray derretia e depois resfriava vários materiais, incluindo enxofre. Aliás, como Gray nota, o enxofre se manteve eletrizado por bastante tempo 52. Materiais que mantêm sua eletricidade por muito tempo são conhecidos hoje como eletretos [53. p. 251-264]. No caso do enxofre, temos um termo-eletreto. Esse efeito de eletrização por motivos térmicos foi estudado experimentalmente pelo físico brasileiro Joaquim de Costa Ribeiro (1906-1960) já no século XX, ficando conhecido como efeito Costa Ribeiro, ou efeito termodielétrico. Costa Ribeiro deu contribuições teóricas à compreensão do fenômeno, mas uma explicação mais completa veio na década de 50, por Bernhard Gross (1905-2002) 54.

85 Aqui, o autor parece contradizer sua ideia de que a forma e a compressão "grosseira" dos materiais não são determinantes no estudo da compressão dos poros onde o éter se encontra. Isso porque afirma que depois do resfriamento, o enxofre, por se reduzir a um espaço de menor volume, tem seus poros encolhidos, sendo que nos dois parágrafos anteriores, alertara o leitor a não reduzir a questão envolvendo a compressão dos poros à compressão do corpo (que ele chama de "grosseira").
} 
esta será de fato negativa, contra a denominação do Sr. Francklin. Entretanto, seria desejável que fizéssemos as mesmas experiências expostas nesses dois últimos parágrafos com outros corpos da primeira espécie, e sobretudo com o vidro, não duvidando que tais experiências muito contribuiriam para confirmar a minha Teoria.

[p. 157]

LVI.

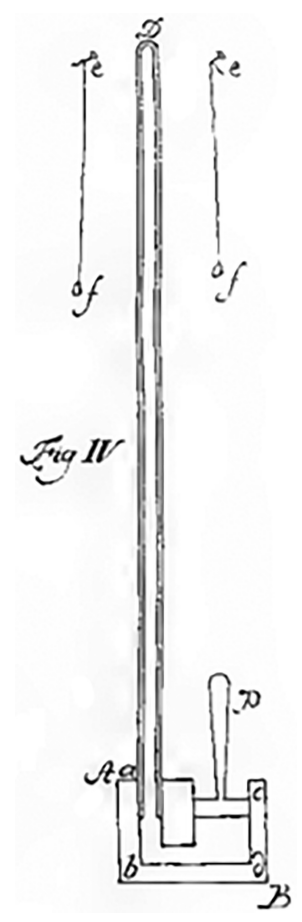

Ora, parece que o Barômetro deveria fornecer o mais seguro meio para esclarecer inteiramente sobre essa dúvida. Examinemos para esse efeito a maneira pela qual nos servimos para nos instruir sobre a eletricidade dos Barômetros luminosos. Encontra-se uma descrição exata disso na dissertação do Sr. Waitz ${ }^{86}$ que ganhou o prêmio sobre a causa da eletricidade proposto pela Academia. Eis aqui um resumo, preenche-se um tubo de vidro fechado por um pouco de mercúrio. Não falarei da maneira mais apropriada de preenchê-lo de sorte que, quando se inclina o tubo, o espaço acima do mercúrio seja um vácuo de ar. Após, perfuram-se dentro de um pedaço de madeira $\mathrm{AB}$ dois canais $a b$ e $c d$, onde o $c d$ é muito mais amplo que o $a b$, cujo diâmetro quase não ultrapasse aquele do tubo de vidro $a \mathrm{D}$, e que esses dois canais tenham uma comunicação entre si, o que acontecerá fazendo-se um terceiro canal $b d$ horizontal de

\footnotetext{
86 Provavelmente Jacob Siegsmund von Waitz (1698-1777). Jacob Waitz escreveu o trabalho "Dissertation sur la cause de l'électricité des corps et des phénomènes qui en dépendent", sem assiná-lo, para uma competição proposta pela Academia de Köningsberg. Ele venceu a competição, cujo resultado foi anunciado em maio de 1745 , e revelou seu nome em um trabalho em alemão sobre a eletricidade intitulado "Abhandlung von der Electricitaet und deren Ursachen" 55.
}

um até o outro. Então, vertendo mercúrio dentro desse canal duplo $a b c d$, e firmando o tubo de vidro $a \mathrm{D}$ dentro do canal estreito $a b$, o barômetro estará feito. Enfim, para fazer subir e descer o mercúrio sem precisar inclinar o barômetro, basta colocar um pistão $\mathrm{P}$ sobre a abertura do canal $c d$. Assim, pressionando o pistão para baixo, o mercúrio subiria, como ao contrário, levantando-o, o mercúrio desceria.

LVII. Para fazer uso de um tal barômetro, bastará, então, suspender nos arredores do tubo leves fios metálicos ef e ef, que serão atraídos e repelidos pelo tubo assim que ele tiver se tornado eletrizado. Examinemos agora os fenômenos que devem acontecer segundo minha Teoria fazendo o mercúrio subir e descer. Que se pressione primeiramente o pistão para baixo, e o mercúrio, subindo, expulsará uma parte do éter puro do alto do tubo para dentro do vidro; o vidro tornar-se-á, com isso, eletrizado positivamente, e os fios metálicos tendo sido atraídos e, do mesmo modo repelidos, sê-loão também. Bastará, então, examinar pelas experiências conhecidas a qual espécie deve ser referida a eletricidade desses fios. Se àquela que o $\mathrm{Sr}$.

[p. 158]

Francklin nomeia positiva, e outros vítrea, ou a negativa do Sr. Francklin, e resinosa para outros. Se as razões alegadas acima fossem fundadas, ela deveria pertencer a resinosa que o Sr. Francklin nomeia negativa, ou então, a resinosa seria de fato positiva, e a vítrea, negativa.

LVIII. O contrário deve acontecer se fizermos novamente descer o mercúrio por meio do pistão porque, então, o espaço interior do tubo acima do mercúrio tendo-se tornado um verdadeiro vácuo, o vidro expulsando aí uma parte do seu éter [para o vácuo] se tornará negativamente eletrizado e, com isso, também os fios metálicos, após terem sido atraídos e repelidos. Então, se a minha Teoria fosse a verdadeira, esses fios deveriam mostrar uma eletricidade vítrea. Ora, o Sr. Wilke, conhecido aqui por suas importantes experiências sobre a eletricidade, confessou-me durante sua estadia aqui [em Berlim] que ele se lembrava de ter examinado a espécie da eletricidade do tubo de um barômetro luminoso após tê-lo inclinado e posto de pé imediatamente, ou seja, após ter feito o mercúrio descer, tendo-o, antes, o feito subir, e ele me assegurou que havia achado que a eletricidade do tubo excitada da maneira supracitada era vítrea, ou seja, positiva segundo o Sr. Francklin. Vê-se, então, ainda aqui que a minha Teoria é a verdadeira e, por isso, dever-se-ia mudar os nomes que o Sr. Francklin dá a essas duas diferentes espécies de eletricidade. Seria, entretanto, desejável que alguns amantes da Física experimental repetissem essas experiências que, por si só, estão em condições de dar à minha Teoria uma certeza incontestável.

LIX. Eis aqui uma outra prova que parece fortalecer esse sentimento. Observamos que todos os corpos da primeira espécie, sendo atritados com um metal, adquirem uma eletricidade vítrea, ou positiva segundo o 
Sr. Francklin, contanto que se faça a exceção do chumbo que sendo atritado contra enxofre produz um efeito contrário ${ }^{87}$ Ora, não é provável que os poros dos metais sejam suscetíveis a uma grande

[p. 159]

compressão porque, já que esses corpos são os mais insensíveis ao atrito, parece que seu éter não pode ser reduzido a um menor espaço pela compressão de seus poros. Então, os poros de todos os outros corpos sendo mais compressíveis, é necessário que, atritando-os contra um metal, nasça [nos outros corpos] uma eletricidade negativa, sendo o éter expulso pela compressão de seus poros. Logo, a eletricidade vítrea será de fato negativa e, com isso, a resinosa, positiva. Se quisermos sustentar o sentimento oposto, dever-se-á dizer que os poros dos metais são mais compressíveis que os de todos os outros corpos, o que não perece estar de acordo com os outros fenômenos da eletricidade; sobretudo a exceção do chumbo, que é necessário fazer em certos casos, pareceria bem surpreendente. Enquanto que no outro sentimento [a teoria de Johann Euler] ela parece bastante natural, devido à moleza desse corpo.

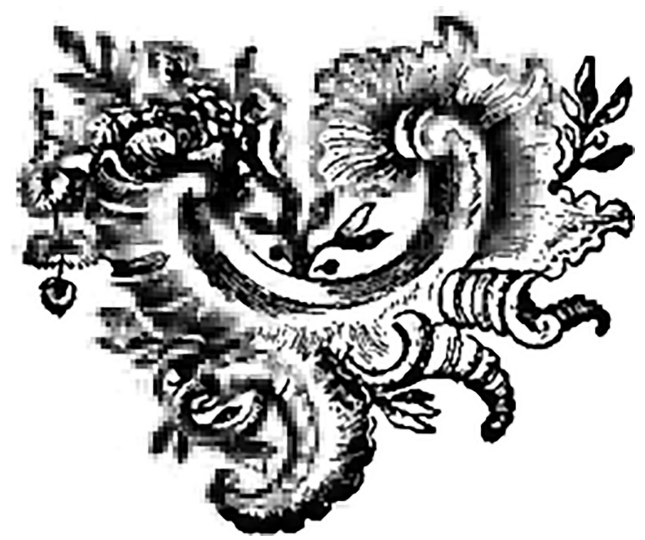

$[\mathrm{FIM}]$

\footnotetext{
87 Johann Euler não está afirmando que eletrizou metais (nãoelétricos per se) por atrito, mas sim que eletrizou elétricos per se (da primeira espécie) atritando-os com chumbo. Nesse caso, o enxofre fica negativo, segundo o autor. Johan C. Wilcke já havia notado que o chumbo fica positivo quando o atrito é com o enxofre, quando o comum é que ele fique negativo [56, p. 63]. Como o chumbo fica positivo, a afirmação de Johann Euler faz sentido, e o enxofre acaba por ficar negativo. $O$ chumbo aqui não é puro, o que o faz um condutor e, portanto, difícil de ser eletrizado por atrito. $\mathrm{O}$ que ele se refere aqui é provavelmente algum composto, isolante, a base de chumbo (como o sulfato de chumbo, que ocorre na natureza). Além disso, é curioso notar que na obra acima mencionada de Wilcke, este dialoga com o trabalho de Jacob Waitz e de Euler (clara referência a Johann Euler). Por exemplo, na página 52 56, ele discute a eletrização do enxofre depois de derretido e resfriado, seguindo o parágrafo LIV acima. Fica claro então que Johann Euler e Wilcke discutiram muito sobre teorias elétricas. Pois, já que o trabalho aqui traduzido é de 1757 (publicado em 1759), e o de Wilcke é de 1757, para que um pudesse citar o raciocínio do outro, só se tivessem trocado muita informação. Como Wilcke trabalhou em Berlim entre 1755 e 1757 [2, p. 384-390], essa troca provavelmente se deu por meio de muita conversa.
}

\section{Referências}

[1] A.K.T. Assis, Os fundamentos Experimentais e Históricos da Eletricidade (C. Roy Keys Inc., Montreal, 2010).

[2] J.L. Heilbron, Electricity in the 17th and 18th Centuries (University of California Press, Los Angeles, 1979).

[3] C. Haakfort, Optics in the age of Euler - Conceptions of the nature of light, 1700 - 1795 (Cambridge University Press, New York, 1995).

[4] C.C. Silva e A.C. Pimentel, em: Filosofia e História da Ciência no Cone Sul. Seleção de Trabalhos do $5^{\circ}$ Encontro, editado por R. de A. Martins, C.C. Silva, J.M.H. Ferreira e L. Al.-C. P. Martins (Associação de Filosofia e História da Ciência do Cone Sul, Campinas, 2008).

[5] R. Jaquel, em: Leonhard Euler 1707-1783: Beiträge zu Leben und Werk, editado por E.A. Fellmann (Birkhäuser Verlag, Basel, 1983).

[6] G. Dulac, Dix-huitème siècle 1, 40 (2008).

[7] C.C. Silva, em: Brazilian Studies in Philosophy and History of Science: an account of recent works, editado por D. Krauser e A. Videira (Springer, London, 2011), v. 290 .

[8] J.A. Nollet, Conjectures sur les causes de l'Electricité des corps ('Imprimerie Royale, Paris, 1749).

[9] C.C. Silva e P. Heering, History of Science 56, 3 (2018).

[10] B.A. Moura, A filosofia natural de Benjamin Franklin: traduções de cartas e ensaios sobre a eletricidade e a luz (EdUFABC, Santo André, 2019).

[11] B. Franklin, A letter from Benjamin Franklin to Peter Collinson, September 1753. Founders Archives, https://founders.archives.gov/documents/Franklin/0105-02-0021, acessado em 27/08/2020.

[12] G. Dulac, Recherches sur Diderot et sur l'Encyclopédie 1, 16 (1994).

[13] R.W. Home, Archives Internationales d'Histoire des Sciences 25, 96 (1975).

[14] R.W. Home e P.J. Connor, Aepinus's essay on the theory of electricity and magnetism / introductory monograph and notes by $R$. W. Home and translation by P. J. Connor (Princeton University Press, Princeton, 1979).

[15] J.A. Euler, Memoires de l'Académie Royale des Sciences et Belles-Lettres 13, 538 (1759).

[16] A.P. Yushkevich, Die Berliner und die Petersburger Akademie der Wissenschaften im Briefwechsel Leonhard Eulers (Akademie-Verlag, Berlim, 1959).

[17] J. von Herbert, Theoriae phaenomenorum electricorum (Vienna, Iosephi nob. de Kurtzböv, 1778).

[18] Hemmer, Observations sur la Physique, sur l'Histoire naturelle et sur les arts (Panckoucke, Paris, 1780).

[19] Y. Gingras, History of Science 39, 4 (2001).

[20] C.C. Silva, A teoria das cores de Newton: um estudo crítico do Livro I do Opticks. Tese de Mestrado, Universidade Estadual de Campinas, Campinas (1996).

[21] S.L.B. Boss e J.J. Caluzi, Revista Brasileira de Ensino de Física 29, 4 (2007).

[22] F. Gandt, Revue du Nord 77, 312 (1995). 
[23] P. Kitcher, em: Companion to the History of Modern Science, editado por R.C. Olby, G.N. Cantor, J.R.R. Christie e M.J.S. Hodge (Routledge, London, 1996).

[24] R.A. Martins, em: Descartes 400 anos: um legado científico e filosófico, editado por S. FUKS (Relume Dumará, Rio de Janeiro, 1998).

[25] M.C.D. Dias, Revista Brasileira de Ensino de Física 39, 4 (2017).

[26] D. Suisky, Euler as Physicist (Springer, Berlim, 2009).

[27] J. Ravetz, Isis 52, 1 (1961).

[28] O. Darrigol e U. Frisch, Physica D: Nonlinear Phenomena 237, 14 (2008).

[29] P. Frisi, em: Dissertationes selectae Johannes Alberti Euleri, Paulli Frisii et Laurentii Béraud, quae ad imperialem scientiarum petropolitanam Academiam an 1755 missae sunt, cum electricitatis caussa $\&$ theoria, Praemio proposito, quaereretur, editado pela Academia de Ciências de São Petersburgo (Petropoli \& Lucae, São Petersburgo, 1757), p. 43.

[30] H.H. Goldstine, A History of the Calculus of Variations from the 17th through the 19th Century (Springer, New York, 1980).

[31] P. Vellando, Foundations of Science 24, 2 (2019).

[32] V.J. Katz, A History of Mathematics: An Introduction (Addison-Wesley, New York, 2009), 3rd ed.

[33] J.D. Jackson, Classical electrodynamics (John Wiley \& sons, New York, 1999), 3rd ed.

[34] L. Euler, Lettres À Une Princesse D'allemagne Sur Divers Sujets De Physique et De Philosophie (Chez Barthelemi Chirol, Genèvre, 1775), v. 2.

[35] D.E. Musielak, arXiv:1406.7417 (2014).

[36] L. Euler, Memoires de l'Académie des sciences de Berlin 11, 217 (1757).

[37] A.F. Chalmers, One Hundred Years of Pressure: Hydrostatics from Stevin to Newton (Springer, Nova York, 2017).

[38] J. Priestley, The History and Present State of Electricity (University of Michigan, London, 1775), v. 2, 3rd ed.

[39] M.B. Hesse, Isis 46, 4 (1955).

[40] O. Darrigol, Electrodynamics from Ampère to Einstein (Oxford University Press, Oxford, 2003).

[41] H.S.T. Santos, D. Gardelli, P.A. Fusinato e M.C.D. Neves, Revista Brasileira de Ensino de Física 42, e20190270 (2020).

[42] I. Newton, Principia: Princípios Matemáticos de Filosofia Natural, Livro II: O Movimento dos Corpos (em Meios com Resistência) (EDUSP, São Paulo, 2008).

[43] R.B. Lindsay, The Journal of the Acoustical Society of America 39, 4 (1966).

[44] L. Euler, Opuscula varii argumenti (Ambr. Haude et Joh. Carol. Speneri, Berlim, 1746), v. 1, p. 169.

[45] J.A. Euler, em: Dissertationes selectae Johannes Alberti Euleri, Paulli Frisii et Laurentii Béraud, quae ad imperialem scientiarum petropolitanam Academiam an. 1755 missae sunt, cum electricitatis caussa $\&$ theoria, Praemio proposito, quaereretur, editado pela Academia de Ciências de São Petersburgo (Petropoli \& Lucae, São Petersburgo, 1757), p. 3.

[46] D.W. Corson, Isis 59, 4 (1968).
[47] R.A. Martins, Cadernos de História e Filosofia da Ciência 1, 9 (1989).

[48] F. Cajori, A History of Mathematical Notations (Dover publications, Inc., New York, 1993), v. 1.

[49] C. Webster, Archives for History of Exact Sciences 2, 6 (1965).

[50] F. Cajori, A History of Mathematical Notations (Dover publications, Inc., New York, 1993), v. 2.

[51] R.W. Home, Isis 67, 1 (1976).

[52] S. Gray, Philosophical Transactions 37, 18 (1732).

[53] A.K.T. Assis, Os fundamentos Experimentais e Históricos da Eletricidade (C. Roy Keys Inc., Montreal, 2010), v. 2.

[54] G.F.L. Ferreira, Revista Brasileira de Ensino de Física 22, 3 (2000).

[55] J.S.V. Waitz, Abhandlung von der Electricitaet und deren Ursachen (Hauder und Spener, Berlim, 1745).

[56] J.C. Wilcke, Disputatio Physica Experimentalis, De Electricitatibus Contrariis (Adler, Rostock, 1757). 